Ragnhild M. Bø*

\title{
Making and Meaning-Making: The Antwerp Altarpiece in Ringsaker (c. 1530) across the Reformation
}

https://doi.org/10.1515/jemc-2020-2019

\begin{abstract}
Antwerp altarpieces produced between c. 1500-1540 could be remarkably similar and have often been regarded as epitomising the shift from bespoke commissions to standardized objects made to be sold on an open market. The only (preserved) Antwerp altarpiece imported to Norway was commissioned by the priest Ansten Jonsson Skonk and put on display in the parish church of Ringsaker shortly before the Reformation was introduced in Denmark-Norway in 1537. Unique in Norway, the altarpiece is of uncommon character even within the larger body of preserved Antwerp pieces. When analysing the many idiosyncrasies of the Ringsaker altarpiece, it comes across as a deliberately versatile product: on the one hand it carefully reflects altarpieces and devotional practices known to Skonk; on the other, it also reflects contemporary religious disputes of northern Europe more broadly, substantiating the claim that (some) Antwerp workshops intentionally created "multi-confessional" artworks - seemingly to suit the patron(s) in question once installed.
\end{abstract}

Keywords: Antwerp altarpieces, Denmark-Norway, patronage, religious visual culture, indulgences, prayer, Eucharist

The appeal of carved and painted workshop altarpieces produced in the Netherlands between c. 1480 and c. 1560 led to the export of around sixty of these to northern kingdoms. Supplementing works acquired from northern Germany, the import of Netherlandish altarpieces into Scandinavia was initiated by Cordt Rogge, Bishop of Strängnäs. In the early 1480s, Rogge commissioned or had an agent commission - two altarpieces from Brussels that were then displayed in Strängnäs Cathedral. ${ }^{1}$ Brussels continued to supply both the

1 On the Strängnäs altarpieces, see Erik Bohrn, Sigurd Curman, and Armin Tuulse, Strängnäs domkyrka, vol. 1, Medeltidens byggnadshistoria, Sveriges kyrkor 100: Text (Stockholm: Generalstabens Litografiska Anstalts Förlag, 1964), 339; Aron Andersson and R. Axel Unnerbäck,

*Corresponding author: Ragnhild M. Bø, University of Oslo, IAKH, PO Box 1008 Blindern, Oslo 0315, Norway, E-mail: r.m.bo@iakh.uio.no 
neighbouring and northern market well into the sixteenth century, but the centre of altarpiece production gradually gravitated towards Antwerp, where it endured until the mid-sixteenth century. ${ }^{2}$ As a result, Antwerp altarpieces abound in Sweden and Denmark, imported by ecclesiasts and members of the nobility or via communal efforts. In Norway, however, there is only a single example - the one imported to the parish church of Ringsaker, a rural yet prosperous agricultural area. ${ }^{3}$ Probably arriving in the late 1530s, the result of a commission by or on behalf of the parish priest, Ansten Jonsson Skonk, the altarpiece has remained in situ, virtually unaffected by Lutheranism and later movements that promoted local variations of Calvinist teachings.

Antwerp altarpieces were in several instances remarkably similar, which indicates that they catered for commonly shared narratives and to late medieval tastes for polychrome sculpture and ornament. As a result, they have often attracted scholarly attention as objects that epitomise the shift from bespoke commissions to a standardized production of objects made to be sold on an open market. ${ }^{4}$ And although recent research has challenged this particular interpretation, consideration of the altarpieces as artisanal objects produced in a

Strängnäs domkyrka, vol. 2, Inredning, Sveriges kyrkor 176 (Uppsala: Almqvist and Wiksell, 1978), 10-12. Comprehensive studies of Netherlandish altarpieces include Hans M. J. Nieuwdorp, ed., Antwerpse retabels, 15de-16de eeuw, 2 vols. (Antwerp: Museum voor Religieuze Kunst, 1993); Lynn F. Jacobs, Early Netherlandish Carved Altarpieces, 1380-1550: Medieval Tastes and Mass Marketing (Cambridge: Cambridge University Press, 1998); Sophie Guillot de Suduiraut, ed., Retables brabançons des XVe et XVIe siècles (Paris: Musée du Louvre, 2002); Ria De Boodt and Ulrich Schäfer, eds., Vlaamse retabels: een internationale reis langs laatmiddeleeuws beeldsnijwerk (Leuven: Davidsfonds, 2007) and Kim Woods, Imported Images: Netherlandish Late Gothic Sculpture in England, c. 1400-1550 (Donington: Shaun Tyas, 2007).

2 Altarpieces were sold from the purpose-built building at the Onze-Lieve-Vrouwepand and from 1484 the artists responsible profited from a municipal decree issued to prohibit the sale of art during the fairs at any other location. The Antwerp artists also profited from the fact that the different métiers included in the production of a large altarpiece (the carpenters, the carvers, the gilders, the polychromers, the painters) were members of the same guild, the guild of St Luke, unlike e. g. the artists in Brussels. 179 Antwerp altarpieces have been identified, whereas the total number of Netherlandish altarpieces surpasses 350. The numbers differ slightly in different publications, mostly because some overviews only record the ones with carved scenes in the corpus. See e. g. the overview in Yao-Fen You, “The 'Infinite Variety' of Netherlandish Carved Altarpieces," in Netherlandish Sculpture of the Sixteenth Century, ed. Ethan Matt Kavaler, Frits Scholten, and Joanna Woodall (Leiden: Brill, 2017), 34-77, in particular p. 35.

3 Admittedly, Ringsaker is the only preserved Antwerp altarpiece in Norway. There is, however, no record of other altarpieces of similar size and content which have been lost.

4 The seminal article on the Antwerp art market remains Dan Ewing, "Marketing Art in Antwerp, 1460-1560: Our Lady’s Pand,” The Art Bulletin 72, no. 4 (1990): 558-84. 
community of new technologies (optics, printing) and contested religious views has not gained much attention. ${ }^{5}$ Unique among altarpieces in Norway, the Ringsaker piece has several characteristics that set it apart from the larger body of preserved Antwerp altarpieces. The inverted T-shape and rounded tops of the wings are features of the body of work previously attributed to the sculptor Robert Moreau. The Ringsaker work, however, differs from this group as well as from most other known Antwerp altarpieces in having sculpted portraits of saints, instead of carved or painted narratives on the inner side of the wings. ${ }^{6}$ It is also a rare example of an altarpiece with a combined Marian- and Passion-centred iconography in the main corpus; and equally unusual is the incorporation of Christ as a Man of Sorrows, the Trinity also being in the main corpus and the inclusion of a sacramental tabernacle below the Crucifixion motif. ${ }^{7}$

This article presents an in-depth analysis of the idiosyncrasies in the Ringsaker altarpiece, preceded by some introductory remarks about the parish church, the commissioner, the iconographical program and the mise-en-scène. Given that both the iconography and the display of the altarpiece reach beyond

5 For scholars contesting or rejecting the term mass-produced all together, see Natasja Peeters and Maximiliaan P. J. Martens, "A Cutting Edge? Wood Carvers and their workshops in Antwerp 1453-1579," in Constructing Wooden Images, ed. Carl Van de Velde et al. (Brussels: Brussels University Press, 2005), 75-92; Godehard Hoffmann, "Compound Altarpieces in Context," Jaarboek Koninklijk Museum voor Schone Kunsten Antwerpen 2004/2005 (Antwerp: BAI, 2005), 74-121; You, "The 'Infinite Variety'," 36 and Susan L. Green, Tree of Jesse Iconography in Northern Europe in the Fifteenth and Sixteenth Century (London: Routledge, 2019), 141-63. Admittedly, Susie Green is among the few scholars who have addressed the contested religious views in her research.

6 Nineteen large altarpieces have been associated with Robert Moreau. The same altarpieces have painted elements associated with the entourage of Pieter Coecke van Aelst. See Elisabeth van Eyck, "BR/154/PI/WINGS AND LINKS - Interdisciplinary Research on Sculpted Altarpieces and Painted Wings" (Brussels: KIK-IRPA, 2018) for the scholarly background and attempts at attributing these altarpieces more accurately. Two Antwerp altarpieces in Sweden, however not associated with Moreau, Folkärna (c. 1500) and Vaksala (1505-1515), also have sculptures of saints on the inside of the wings. Folkärna is smaller and has three sculptures in the corpus, whereas Vaksala has the same number of compartments and the same narrative mode as have Ringsaker and most other Antwerp altarpieces of equal size.

7 Many altarpieces contain a combination of scenes from Christ's Childhood, the Passion and the Life of the Virgin, but the three cycles are often delegated to different parts of the altarpiece, for example in having scenes from the Passion sculpted in the corpus and a Marian iconography in the painted wings (Coesfeld) or Passion scenes in the main corpus and scenes from Christ's childhood in the predella (Frustuna). Ringsaker is almost unique in having two Marian motifs flanking the Crucifixion in the corpus, the other extant altarpiece with a similar combination is the one in Boslar. Moreover, the Zulpich II has the Coronation of the Virgin below the Crucifixion, thus a Marian scene included in an otherwise Passion-centred iconography in its corpus. 
the conventional and formulaic, it is regarded as insufficient to view the work as a standardized product. Rather, by attending to its particularities through the lenses of contemporary artisanal practices, religious and epistemological currents and the role of the commissioner, I argue that the Ringsaker altarpiece is a versatile artistic product - an altarpiece among many that "were called upon to do something new or different, to test the limits of decorum in religious art which they inherited." 8 On the one hand, it carefully reflects altarpieces and artistic trends known to Skonk and also corresponds with the formulas of contemporary prayers and indulgences known both to him and the local congregation; on the other hand, it can also be reasoned that the altarpiece reflects contemporary religious disputes of northern Europe, thus substantiating the claim that Antwerp artists intentionally created "multi-confessional" artworks.

\section{The altarpiece in Ringsaker: Context, content, commission}

The church of Ringsaker is a medieval basilica dedicated to St Olaf. Construction began in the latter part of the twelfth century, subsequent to the establishment of the bishopric of Hamar in 1153. The choir was extended shortly before 1300, and the spire in its present structure was not erected until 1694. Larger than the single-nave stone churches regularly built in south-eastern parts of Norway of this time, Ringsaker probably served as the fylkeskirke for an area greater than the parish. ${ }^{9}$ Although the church itself is virtually unaltered, traces of its medieval decoration and medieval inventory are reduced to remnants of murals and the Antwerp altarpiece on the main altar (Figures 1 and 2). ${ }^{10}$

8 Craig Harbison, "The Northern Altarpiece as a Cultural Document," in The Altarpiece in the Renaissance, ed. Peter Humfrey and Martin Kemp (New York: Cambridge University Press, 1990), 73.

9 The function and size of Ringsaker would be equal to those of Gamle Aker, St Nicholas (Gran), Hoff, Tjølling and St Lawrence (Tønsberg). The similarities are less visible today; St Lawrence was demolished (1810) and the churches at Hoff (1703) and Tjølling (eighteenth century) have been largely altered. See Øystein Ekroll, Med kleber og kalk: Norsk steinbygging i mellomalderen (Oslo: Samlaget, 1997), 31-32.

10 A wooden chalice now in the Museum of Cultural Heritage, University of Oslo (Inv. no. Cf10066) is registered as having come from Ringsaker, thus very probably from the parish church. Other valuable items are the baptismal font still in situ and a baptismal house from 1713, now in Folkemuseet, Oslo (Inv. no. NF.1941-0148). Gerhard Schøning observed two aged candelabra on the altar carrying two different coats of arms, one belonging to the Gyldenhorn family, cf. Gerhard Schøning, Reise gjennem Hedemarken 1775 (Hamar: Hamar Stiftstidendes 


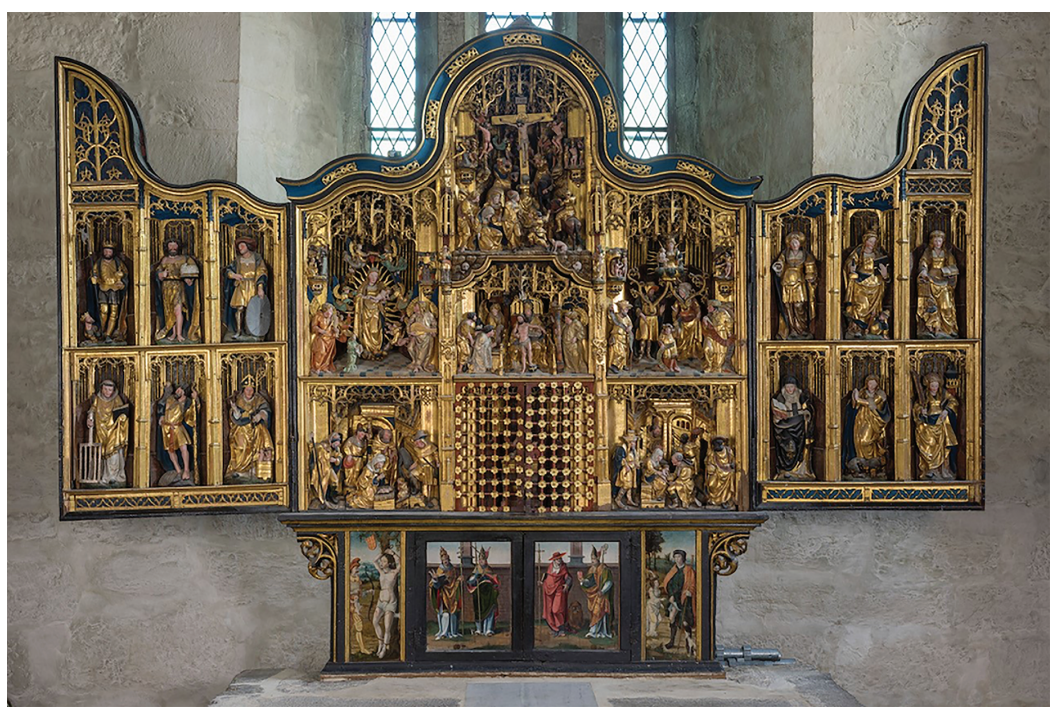

Figure 1: The Antwerp altarpiece in Ringsaker (c. 1530), open position.

Photo: Birger Lindstad @ NIKU

The altarpiece has been the subject of a handful of books and articles, all of which have their point of departure in the brief mentioning of the work in the Visitation book of Bishop Jens Nilssøn, who saw the altarpiece in 1594, and in the description of the work provided by the historian Gerhard Schøning during his travels in southeastern Norway in $1775 .{ }^{11}$ A local nineteenth-century vicar, Reinert Svendsen, further analysed the work; but the most thorough study of the altarpiece remains the 1955 publication by archaeologist and museum curator Sigurd Grieg. ${ }^{12}$ In three

trykkeri, 1942), 16. An inventory written around 1800 (discovered in 1963) also mentions the candelabra, believing them to be from Catholic times. The inventory also mentions a very valuable altar frontlet with the twelve apostles on it. Most unfortunately, this has been lost. The candelabra, however, date from the 1540s, cf. "Transcription from 1963," Directorate of Cultural Heritage, Oslo.

11 Yngvar Nielsen, ed., Biskop Jens Nilssøns Visitatsbøger og reiseoptegnelser 1574-1597 (Kristiania [Oslo]: A. W. Brøgger, 1885); Schøning, Reise gjennem Hedemaken, 9-20.

12 Reinert Svendsen, Ringsaker kirke paa Hedemarken: En beretning om dens tilblivelseshistorie af pastor Reinert Svendsen (Kristiania [Oslo]: Aschehoug, 1899); Sigurd Grieg, Ringsaker kirkes gamle herlighet: kulturhistoriske studier over nederlandske og nordtyske alterskap i Norge (Lillehammer: De Sangvinske samlinger), 1955. 


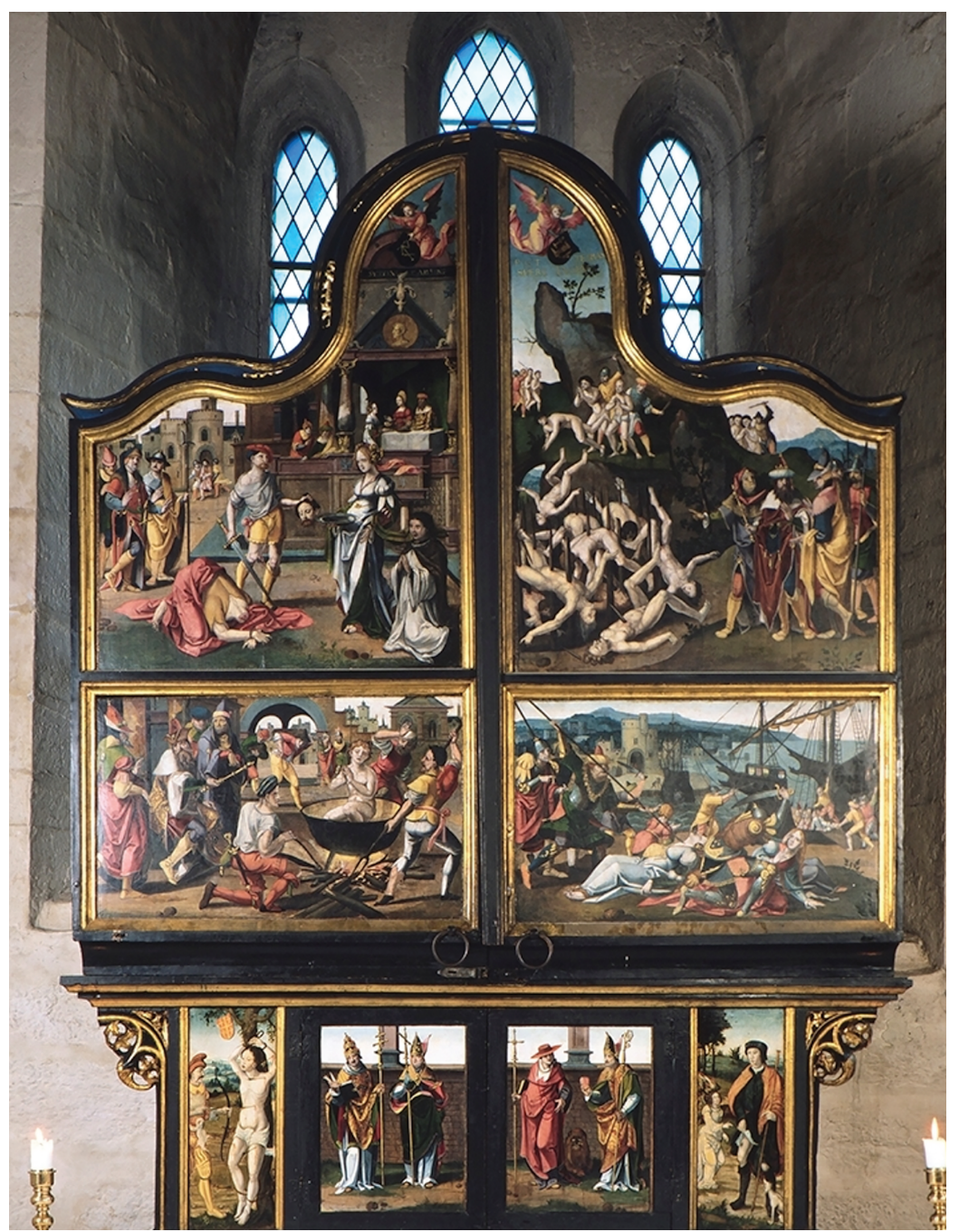

Figure 2: The Antwerp altarpiece in Ringsaker (c. 1530), closed position. Photo: Jan Haug @ Anno Domkirkeodden

later articles, the altarpiece has been approached from art-historical, iconological and material-sensorial perspectives. ${ }^{13}$

13 Anne Kjellberg, “Alterskapet i Ringsaker kirke: dets plass i kunsthistorien,” Kunst og kultur 60, no. 1 (1977): 19-38; Nils Ytreberg "Ringsaker kirkes alterskap i kulturhistorisk lys,” Kunst og kultur 61, no. 1 (1978): 23-42; Kaja M. Haug Hagen, "Senmiddelalderens betrakter og Ringsaker 
The main corpus of the altarpiece - the caisse - is divided into seven compartments of sculpted scenes. The central compartment contains the Crucifixion, the Trinity (in the form of a "Throne of Mercy") and Christ as the Man of Sorrows. On either side of the Crucifixion and Trinity the Apocalyptic Madonna and the Arbor Annae are depicted, while the Adoration of the Shepherds and the Adoration of the Magi are placed on either side of the Man of Sorrows. When open, the shutters display statues of an entourage of twelve saints, six on either side. In the left shutter are St Olaf, St John the Baptist, St Hallvard, St Lawrence, St Christopher and St Nicholas; in the right are St Mary Magdalene, St Catherine, St Dorothy, St Gertrude, St Margaret and St Barbara. When closed, these shutters offer images of the martyrdom of St John the Baptist; the boiling of John the Evangelist (left) juxtaposed with St Acacius and the ten thousand martyrs at Mount Ararat; and the death of St Ursula and the eleven thousand virgins (right), all painted in the style of Antwerp Mannerism. ${ }^{14}$ The caisse measures $212 \times 200 \mathrm{~cm}$ and all the sculpted narrative scenes unfold in niches that are $25 \mathrm{~cm}$ deep, scenically staged on inclining planes. ${ }^{15}$ The altarpiece rests on a predella that depicts the Last Judgment flanked by side panels with painted representations of St George fighting the dragon (left) and St Sebastian (right). When closed, the smaller shutters reveal paintings of four Church fathers in the centre, and beside them paintings of St Sebastian (left) and St Rochus (right) can be seen. ${ }^{16}$

The mark of the beeldensnijders (carvers) - an open hand - is found on all the individual figures in the sculpted scenes and allows a secure attribution of

kirkes alterskap: Mellom presentasjon og representasjon,” Kunst og kultur 100, no. 3 (2017): $146-61$.

14 First used by Max Friedländer, the term Antwerp Mannerism designates the superficial manner with which (mostly) anonymous sixteenth century artists, ensembled as PseudoHenry de Blees, treated their religious motifs, see Max Friedländer, "Die Antwerpener Manieristen von 1520," Jahrbuch der königlich preußischen Kunstsammlungen 36 (1915): 65-91. On Antwerp Mannerism, also see Maximiliaan Martens and Peter van den Brink, eds., ExtravagAnt! A Forgotten Chapter of Antwerp Painting 1500-1530 (Antwerp: BAI, 2005).

15 The caisse and all the figures are carved in oak and fashioned with polychromy and gilding. 16 The painted scenes are all in oil (in the report it is stated the painting is tempera, probably because of the light hues) on oak supports. The altarpiece is in fairly good condition and has preserved much of the original polychromy. It was partly restored in 1968-69 and again in 1982. The shutters were removed for technical conservation in 1970-73. During conservation, dirt and varnish were removed, and flakes of gilding and polychrome layers were affixed. The upper trim was repainted, and some lost ornaments were copied and inserted in order to have the altarpiece appear as coherent as possible, cf. Janne Bakken's report from July 14, 1985, Directorate for Cultural Heritage, Oslo. The Norwegian Institute of Cultural Heritage (NIKU) currently runs technological investigations on the altarpiece. Results are expected to be published in 2021. 
the altarpiece to an Antwerp workshop (Figure 3). ${ }^{17}$ Because of the shape and format of the altarpiece and the stylistic features of the figures, the Ringsaker altarpiece was long considered to be among those works associated with the sculptor Robert Moreau, active in Antwerp between 1533 and 1540. ${ }^{18}$ Attributions of Antwerp altarpieces to a single master, however, have proved possible only under certain circumstances, as the corporate system of production, and the social and professional mobility of Antwerp artisans, often precluded stylistic unity. The polyphonic nature of stylistic expression combined with the absence of named artists are likely two key reasons why such Antwerp productions have been considered to be prefabricated works without artistic traces and assumed artistic values. The lack of stylistic unity, however, should not be understood as

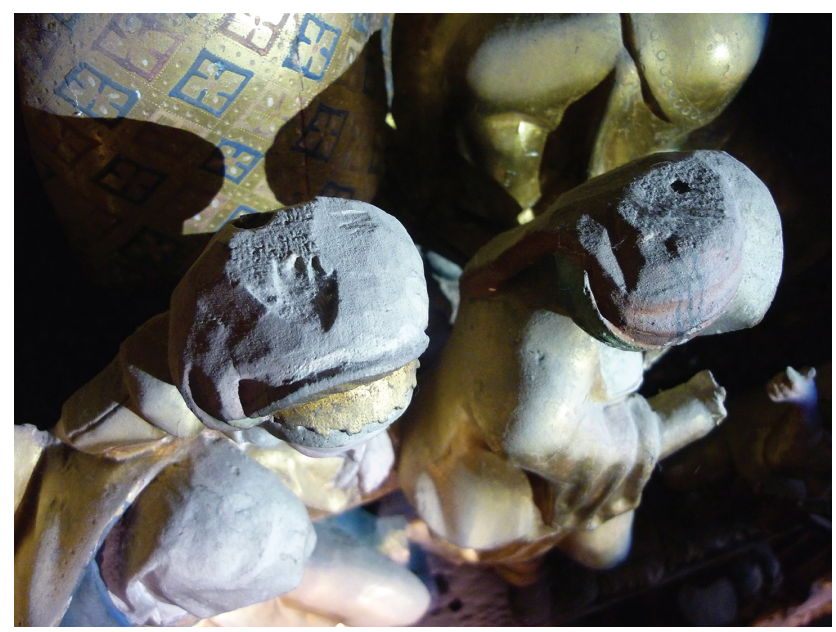

Figure 3: Mark of the Antwerp carvers, detail from the altarpiece in Ringsakar (c. 1530). Photo: Ragnhild M. Bø

17 The Antwerp city mark is found in several places on the caisse and all the figures have an impressed hand either on the bases or on their head. On the features of Antwerp altarpieces in relation to the ones from Brussels and Mechelen, see Myriam Serck-Dewaide, "Support and Polychromy of Altarpieces from Brussels, Mechlin, and Antwerp: Study, Comparison, and Restoration," in Painted Wood: History and Conservation, ed. Valerie Dorge and F. Carey Howlett (Los Angeles: The Getty Conservation Institute, 1998), 82-99.

181533 Robbert Moau, beldsnydere, cf. Philippe F. Rombouts and Théodore Van Lerius, eds., De Liggeren en andere historische archieven der Antwerpsche Sint Lucasgilde (Antwerp: Feliciaen Baggerman, 1872), 119. As for the nineteen altarpieces associated with him, further publications are to be expected in the wake of the WINGS and LINKS-project, see Élisabeth Van Eyck, "Wings \& 
a lack of artistic ambition or concern for the final product within the workshops. As Natasja Peeters and Maximiliaan Martens have noted, "the size and structure of the workshops were obviously geared towards artisanal and not towards semi-industrial production of sculptures."19 Likewise, I consider the carvers, painters and polychromers involved in the Ringsaker altarpiece to have acted according to their own artistic agencies - while also responding to the wishes of the commissioner - but I do not delve into details concerning their identity or deciphering the number of hands involved in the making of it.

Even though identifying the responsible hands is challenging, determining the identity of the commissioner is not. He is portrayed in paint, kneeling and witnessing the death of St John the Baptist, and as a sculpted figure consorting with St John the Baptist and angels before the Trinity (Figure 4). In addition to these images of the donor, an added inscription - Hanc Tabulum Fieri Fecit Mag. Anstanus Jonæ Orate Deum Pro Anima Ejus - and a coat of arms above the Martyrdom of the Ten Thousand allows us to establish that this kneeling priest is Ansten Jonsson Skonk (d. 1547). ${ }^{20}$ Skonk's role is further evidenced from a nowlost inscription on the shutters. Composed in Latin and in the form of a hexameter, it reads:

Hanc sibi divino concessis numine donis

Donavit tabulam diversis undique ornatam

Picturis ædi sacratæ optimus Anstanus Schonck eximiuxque Magister

- Asloiæ - que divini semine verbi

Commisum nutrire gregem pastor bene novit

- Nituntur - que hac aspicis atque animam optat requiescere coelo ${ }^{21}$

Links. Nouvelles hypothèses sur la production de retables anversois des années 1530-1540 à partir du groupe dénommé autrefois 'Moreau',” Bulletin de l'IRPA 35 (2016-2018): 63-105.

19 Peeters and Martens, "A Cutting Edge?," 90. On individual masters, see Ulrich Schäfer, "Is it possible to describe the personal style of an Antwerp carver?," in Van de Velde et al., Constructing Wooden Images, 27-50.

20 "Mag[ister] Anstein Jonsson Skonk had this altarpiece made. God pray for his soul," cf. Schøning, En reise, 15. The very unusual formula "God pray for his Soul" has been interpreted as the writer's attempt not to ask anyone in the congregation to pray for Ansten's souls, as that would mean asking for a Catholic practice. Skonk, also written Skanke or Skonck, is the name of a noble family.

21 "For funding given him by divine grace, he has donated this altarpiece, completely ornate with different images, to this holy temple - the honourable and excellent Magister Ansten Skonk - from Oslo - as shepherd he understands well how to nurture the confided flock with the seeds of the divine word - and you see this and you want the soul to rest in heaven" (author's translation), see Schøning, En reise, 15 and Grieg, Ringsaker kirkes gamle herlighet, 78. The inscription was written where the frames would meet when the shutters were closed. 


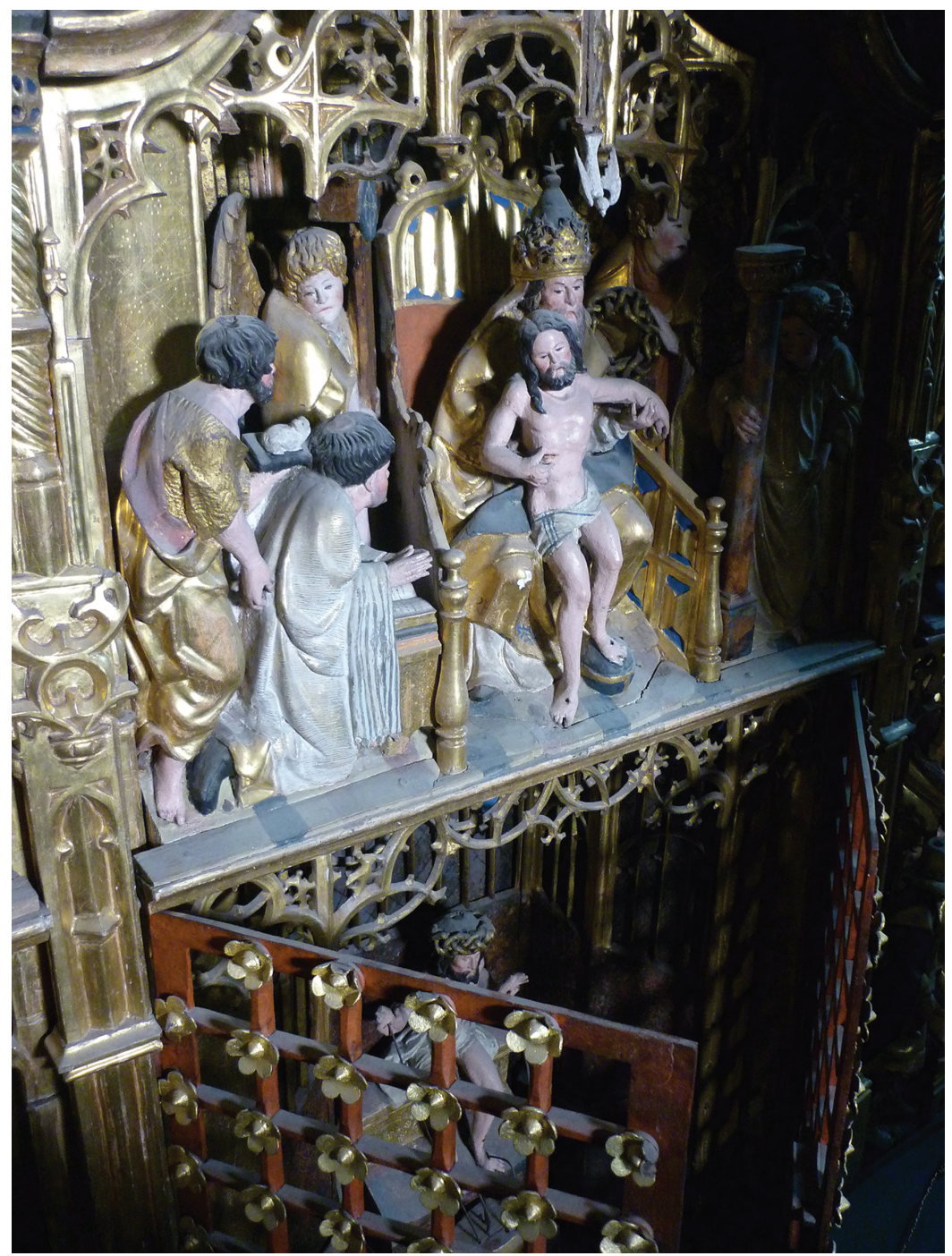

Figure 4: Ansten Jonsson Skonk presented to the Trinity (Throne of Mercy) by St John the Baptist, detail from the altarpiece in Ringsaker (c. 1530).

Photo: Ragnhild M. Bø

The inscription recalls how the priest Ansten Jonsson Skonk was afforded the means to embellish the church with this altarpiece; it was probably added sometime between Skonk's death in 1547 and Bishop Jens Nilssøn's official visitation to the church in 1594 when, as it were, Bishop Nilssøn wrote that 
the altarpiece had no equal anywhere in Norway. ${ }^{22}$ No longer legible, owing to some repainting done in the nineteenth century, the inscription was first recorded by Christoffer Ancher in 1743, and could probably still be deciphered in the 1770s, when Gerhard Schøning recorded it in his travel diaries. ${ }^{23}$

Aside from his role in conveying a lavish altarpiece to his parish church, there is hardly enough documented material to establish a firm timeline of Skonk's life and career. Written records indicate that he acted as an intermediator in a few disputes over property and fishing privileges, but they are silent about his interest in commissioning artefacts. We know, though, that Skonk received theological education from Rostock, where he was registered as a student in $1513 .^{24} \mathrm{He}$ may, however, have acted as priest in Ringsaker as early as 1504 and again from 1514, serving as the last Catholic priest and the first Lutheran minister in the parish. Some scholars, in attempting to explain his retention of the office, have suggested that Skonk developed a receptive attitude towards Lutheran ideas during travels abroad. But Skonk's situation was not unique; many Catholic priests remained in their offices for the pragmatic reason that in the years following the Reformation there would have been no others to replace them. ${ }^{25}$ In addition to his service in Ringsaker, Skonk also held the prebendary at the Corpus Christi altar in Hamar Cathedral and a prebendary in St Hallvard, the cathedral of Oslo. ${ }^{26}$ The funding alluded to in the inscription may thus have derived from these incomes.

22 "Ringesager kircke er en skiøn stor stenkirche, korskircke, met vinger och spir, som Maz taarnbygger nu bygger paa, der er och en saare skiøn taff1e til alterit, saa att der icke findis en skiønnere vdj Norge, huilcken en ved naffn M. Ansteen Skonck, haffuer ladit giort och staar hans naffn beneffnd der paa vdj nogle verss som der er schreffuit vden paa tafflen (...)" [The church of Ringsaker is a beautiful large church of stone in the form of a Latin cross, with transepts and a spire about to be constructed by Maz spirebuilder; there is also a very beautiful retable on the altar, indeed there are not any more beautiful in the entire Norway, one that M. Ansteen Skonck let be produced and his name is mentioned in some verses written on the retable (...)] See Jens Nilssøns Visitatsbøger, 304. Nilssøn assisted the sermon on September 14, 1594.

23 Schøning, En reise, 15.

24 Grieg, Ringsaker kirkes gamle herlighet, 84.

25 See Martin Schwarz Lausten, "Kirkens nye ordninger," in Reformasjonen i dansk kirke og kultur 1517-1700, ed. Niels Henrik Gregersen and Carsten Bach-Nielsen (Odense: Syddanske Universitetsforlag, 2017), 161-206. Also see Tarald Rasmussen, "The Early Modern Pastor between Ideal and Reality," Lutherjahrbuch 80 (2013): 197-219.

26 Grieg, Ringsaker kirkes gamle herlighet, 87. Also see Nicolay Nicolaysen, Stor-Hammers nuiner: Historisk Beskrivelse (Kristiania [Oslo]: J. Chr. Gundersens Bogtrykkeri, 1893), 17; and Norske registranter, vol. 1, 156: “Til Jens Thomessøn, Cancelleriskriver, fik, kvit og fri og uten al Tyngde, til sin underholdning det Præbende og Kannikedom i Oslo Domkirke, og den Rente i Hamars Domkirke, som faldt etter Mr Ansteen, som han nu selv i Værge har, men al sin Rente og rette Tilliggelse udi hans Livstid (...)." [To Jens Thomessøn, chancellor, received without further inquiries for him to have the prebendary and the canon position in Oslo cathedral, and the income from Hamar cathedral which 


\section{Ringsaker and late medieval altarpieces: Antwerp and beyond}

When compared with most other Antwerp altarpieces, the one in Ringsaker is idiosyncratic mostly in terms of the twelve sculpted saints on the inner side of the shutters; the choice of saints; the combined Marian and Passion iconography in the main corpus; and the incorporated sacrament tabernacle. Given that the commissioner is known, some of these features may be traced back to other altarpieces known by Skonk or his closest advisers or assistants. Other aspects of the work seem to result from decisions within the Antwerp workshop, which, as pointed out above, were comprised of artists of different métiers who exercised their own agency upon the final product, and who took advantage of the available circulating drawings, model books and wood blocks. In addition to cost-efficient practices within the St Luke's guild and the favourable trading conditions at the Pand, the flourishing printing business also contributed to such circulations. ${ }^{27}$ With reference to the sixteenth-century Flemish painter Pieter Coecke van Aelst, Elizabeth Cleland has thoughtfully explained:

In his drawn designs, Coecke understood that, as well as expressions of his own creativity, these were models to copy, tools to guide, images to be translated into other media, whether the wool and silk polychrome threads of tapestry, the woodblock cuts for printing, the stained and colored fired-glass panels for windows, or (...) the cast and bejeweled goldsmith's work encasing a wonder of the natural world. ${ }^{28}$

We do not know why Skonk and/or the congregation in Ringsaker wanted an altarpiece from Antwerp, and assessing the popularity of these and other imported altarpieces this far north is precluded by the lack of contracts and inventories, as well as by later relocations of the ones preserved. ${ }^{29}$ Moreover, the

had belonged to Mr Ansteen, which he himself in the role of protector do possess, but with all the interests and all rights to have all his life (...)]. The letter was written in Copenhagen July 26, 1552.

27 From around 1520, Antwerp commanded more than half of the printing output in the Netherlands, thus speeding up circulation to hitherto unknown degrees. See Andrew Pettegree and Malcolm Walsby, eds., Netherlandish Books: Books Published in the Low Countries and Dutch Books Printed Abroad before 1601 (Leiden: Brill, 2011), xiii.

28 Elizabeth Cleland, in Grand Design. Pieter Coecke van Aelst and Renaissance Tapestry (New Haven and London: Yale University Press, 2014), 8. As this is said in regard to painting, similar practices of sharing may have taken place among carvers, most recently proved by the meticulous analysis of three Antwerp altarpieces in Green, Tree of Jesse, 62-64.

29 Hannah De Moor, "Moving altarpieces: tracing the provenance of Netherlandish carved altarpieces in Sweden,” Konsthistorisk tidskrift/ Journal of Art History 88, no. 4 (2019): 185-204. 
differences in altarpiece importing between the three kingdoms of Denmark, Norway and Sweden, although at the time joined under one single monarch in

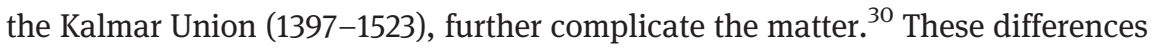
in importing, however, follow differences in broader trading patterns: whereas well-established trading networks of Lübeckers and Hollanders operated in Norway, it seems trade, diplomacy and ecclesiastical links between Norway and Brabant were much less prominent than were the links between Brabant and the other two countries in the union. ${ }^{31}$ Nevertheless, the commissioning of the Ringsaker altarpieces may have been motivated by itinerant merchants advertising for Brabantine altarpieces, offering Skonk the possibility to follow the trend which was initiated in Sweden, with the import of Brussels altarpieces to Strängnäs Cathedral in the early 1490s, and in Denmark with King Christian II's presumed commissions of Antwerp altarpieces in the second decade of the sixteenth century. These latter orders, however, were the result of prodding by the king's Mechelen-born wife, Isabella of Austria, and his travels - and later exile - to the Netherlands. ${ }^{32}$ Indeed, the fashion for Antwerp "things" extended

30 The most comprehensive published overviews of late medieval altarpieces in Scandinavia remain Aron Andersson, Medieval Wooden Sculpture in Sweden, vol. 3, Late Medieval Sculpture (Stockholm: Almqvist and Wiksell, 1980), 185-216; Eivind Engelstad, Senmiddelalderens kunst $i$ Norge ca. 1400-1535 (Oslo: Universitetets oldsaksamling, 1936); and Sidsel F. Plahte and Jens Bruun, Danmarks middelalderlige altertavler og anden billedbærende kirkeudmykning af betydning for liturgien og den private andagt (Odense: Syddansk universitetsforlag, 2009). Recent research on altarpieces in Scandinavia has been primarily concerned with production techniques and provenance, see e.g. Kristin Kausland, "Late medieval altarpieces in Norway: Domestic, imported, or a mixed enterprise?" Zeitschrift für Kunsttechnologie und Konservierung 30, no. 1 (2016): 47-66; Noëlle Streeton, "Perspectives (Old and New) on Late Medieval Church Art in Norway: Questioning the Hegemony of Lübeck Workshops," Scandinavian Studies 90, no. 1 (2018): 50-77 and De Moor, "Moving altarpieces."

31 On the trading routes and fisheries in the North Sea, see e. g. Justyna Wubs-Mrozewich, Traders, Ties and Tensions: The Interaction of Lübeckers, Overijsslers and Hollanders in Late Medieval Bergen (Hilversum: Verloren, 2008), and Louis Sicking and Darlene Abreu-Ferreira, eds., Beyond the Catch: Fisheries of the North Atlantic, the North Sea and the Baltic, 900-1850 (Leiden: Brill, 2009). For the networks trading in altarpieces in the Baltic Sea, see publications by Jan von Bondsdorff such as "Spridningen av senmedeltida träskultur i Nordeuropa - alternativa forskningsstrategier," Collegium medievale 13 (2000): 185-201 and Kunstproduktion und Kunstverbreitung im Ostseeraum des Spätmittelalters (Helsinki: Finska forminnesföreningens tidskrift, 1993).

32 Lars Bisgaard, Christian 2. En biografi (Copenhagen: Gads forlag, 2019), 290-313 and Ulla Haastrup and Fritze Lindahl, "Hellig tre konger altertavlen fra Nykøping," Nationalmuseets arbejdsmark, ed. Erik Kjersgaard (Copenhagen: National Museum, 1970), 119-30. Isabella may have contributed to the import of Netherlandish altarpieces to Norway, too, through her connection and commitment to Erik Valkendorf, Archbishop of Nidaross, see Tone Olstad, “The so-called 'Leka group': New Information based on Examination of Four Triptychs,” in 
well beyond altarpieces: for example, the largest output of translations of Luther's writings into Danish were printed in Antwerp. ${ }^{33}$

However, from the few written records that offer biographical information about Skonk, none provide details concerning pious donations to churches - a rather surprising fact considering the highly precious nature of an artefact such as the Ringsaker altarpiece. The few church inventories that have survived from late medieval Norway tend to focus on valuable metallic objects, such as chalices, patens and liturgical crosses - that is, objects of gold and silver, for which it was easier to assess weight and monetary value. In a letter sent from Christian III to his chancellor Eske Bille in 1537, the same year the Reformation was introduced in Denmark-Norway, the king demanded that Bille seize the Bergen diocese on his behalf. The king further advised that, in the process, Bille should "make sure that nothing is taken away, such as chalices, discs, monstrances, treasures in gold and silver, gilded altarpieces or other such houses [sacramental tabernacles or sacramental towers] which are in churches and monasteries.” ${ }^{34}$ The letter offers a glimpse into the late medieval church space and establishes that gilded altarpieces were acknowledged by king and chancellor - and thus assuredly also among local parish priests and parishioners - to be on a par with items of silver and gold.

Moreover, because so few medieval objects remain in Ringsaker, we do not know which kinds of artefacts - let alone their pictorial content - the altarpiece was thought to complement or even replace. The situation is equally unfortunate for most other churches Skonk would have been familiar with, such as the two in which he held a prebendary, the cathedrals in Hamar and Oslo. Along with the Corpus Christi altar in Hamar Cathedral, there were altars devoted to the Five Holy Wounds, St Anne (founded between 1470 and 1495), St Catherine (before 1500), St Nicholas, the Holy Cross, the Fifteen Holy Helpers, St Michael, the Virgin Mary (after 1512), and the Saviour (also after 1512). ${ }^{35}$ Each of these altars

Paint and Piety: Collected Essays on Medieval Painting and Polychrome Sculpture, ed. Noëlle L. W. Streeton and Kaja Kollandsrud (London: Archetype, 2014), 161-80.

33 See the list of translations printed before 1535 s.v. "Luther" and "Danish" in Early European Books online through ProQuest, https://search.proquest.com/eeb.

34 “ (...) och at i thet saa skicke at ingtet forryckes aff kalcke disk monstrantier clenodier guld siølff forgyltte taffuller och andit saadant hues som er eller findis vdi kircker och closter (...).” Diplomatarium Norvegicum, 22 vols. (Oslo: Riksarkivet, 1847-2011), vol. 3, 1147 (henceforth abbreviated DN).

35 An altar devoted to the deceased (defunctorum) is mentioned only once, in 1284. From these ten altars dated before the Reformation, eight could still be traced in the cathedral's ruinated state in 1893. See Nicolaysen, Stor-Hammers ruiner, 17. 
would have had some form of fairly contemporary altar embellishments which could have resonated with items in Ringsaker and thus have inspired Skonk. ${ }^{36}$

The cathedral of St Hallvard in Oslo was the second largest church in medieval Norway and was filled with splendour. The embellishments of St Hallvard's may have included a small thirteenth-century altar cross from Limoges, some liturgical gear/vestment(s), as well as an altarpiece now known from its later home in the parish church in Onsøy (Figure 5). ${ }^{37}$ The altarpiece has been attributed to Claus Berg's workshop in Odense and dated c. 1520. It was purportedly commissioned by Gro Gyldenhorn, who had given it to an unspecified convent in Oslo. Eivind Engelstad has suggested, based on the representation of the Trinity as a "Throne of Mercy" in the central compartment, that the

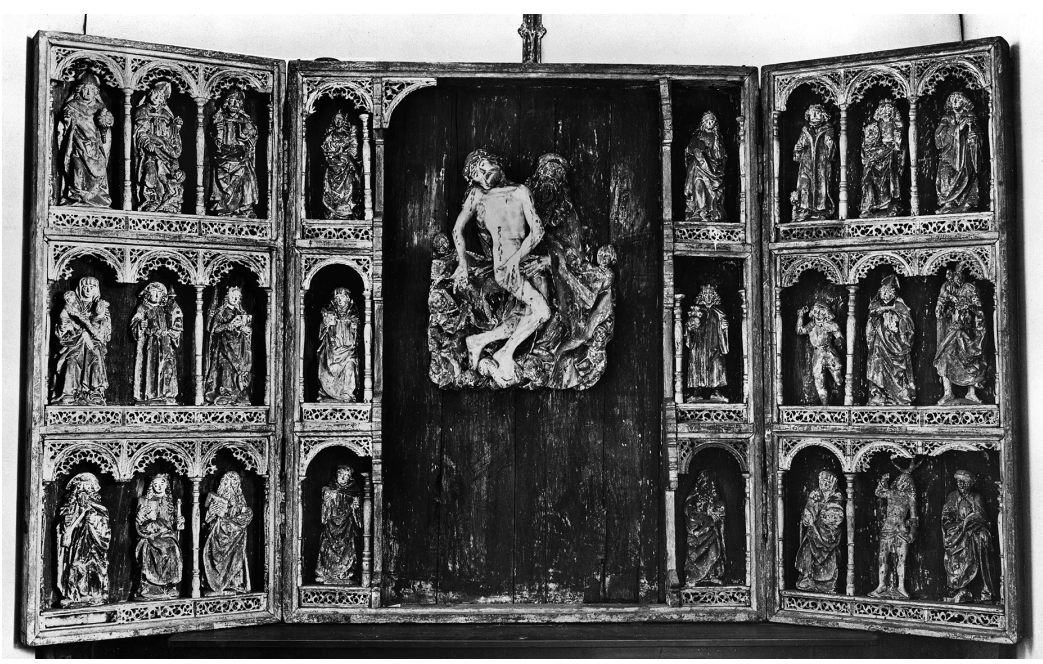

Figure 5: Altarpiece from Onsøy church, 1500-1530. Oslo, Museum of Cultural History, Inv. no. C9896.

Photo: Unknown. () Museum of Cultural History, University of Oslo/ CC BY-SA 4.0

36 The only item preserved from the cathedral is a fifteenth century door which is now in the sacristy of Nes parish church. It has floral fittings in bronze and carries the inscription ave Maria gracia. It is not known where the door was placed originally. It is of significance, however, that it was preserved and reused as spolia in a nearby church. Its flowery decoration does resemble the latticework found on the sacramental tabernacle in the Ringsaker altarpiece The door was probably brought to Nes at the same time as stone was taken from the redundant cathedral in order to erect the sacristy in or during the subsequent building projects in 1698 and 1706, cf. Nicolaysen, Stor-Hammers ruiner, 9-10.

37 Oslo, Museum of Cultural History, Inv. no. C9896. 
Onsøy altarpiece may have been commissioned by Gyldenhorn to adorn the Corpus Christi altar in St Hallvard. ${ }^{38}$ If it did indeed embellish the Corpus Christi altar, or any other altar in St Hallvard, the Onsøy altarpiece may have influenced Skonk's commission.

In addition to sharing the Trinity, the mise-en-scène of the Onsøy and Ringsaker altarpieces are similar, although in the former there are twenty-four figurines of saints in the wings, whereas in the latter there are twelve. ${ }^{39}$ The disparity in number, though, may be a result of different locations in the churches' interiors. If it embellished the Corpus Christi altar, the Onsøy altarpiece would have been placed on a side altar, and thus be visually accessible to most churchgoers, whereas the Ringsaker altarpiece is placed at the main altar at the end of an extended choir, and as a result, often was only partially visible and almost never accessible. Reducing the number of saints would increase their visibility. As many altarpieces from northern Germany have sculptures of the apostles in the wings, twelve is almost a given. One example is the Lübeck altarpiece brought to Bergen in the late 1400 s. $^{40}$ Embellishing the main altar of St Mary, the church of the German traders resident in the town, the corpus contains the Apocalyptic Madonna surrounded by St Olaf, St Catherine, St Dorothy and St Anthony, along with the Twelve Apostles in the shutters. The Mass of St Gregory is depicted on the outside of the shutters, as are three scenes from the Infancy Cycle. ${ }^{41}$

These altarpieces may not have served as direct models for the altarpiece in Ringsaker, but Skonk possibly found in them "tools to guide," at least in terms of sculptured figures on the inner side of the shutters. In addition to probably requesting the indigenous saints Olaf and Hallvard, Skonk may also have been instrumental in the inclusion of St Gertrude. She is not present in any medieval religious artefacts in Norway apart from in Ringsaker and the altarpiece in Rissa (Utrecht? c. 1520), and her inclusion here is all the more intriguing because St Gertrude is not found in any other preserved Antwerp workshop altarpiece from the period either. This strengthens the hypothesis that her presence was specifically requested by Skonk, possibly because he was familiar with her from Rostock, where a hospital and adjacent chapel had been founded in her name in $1468 .^{42}$

38 Engelstad, Senmiddelalderens skulptur in Norge, 212.

39 The altarpiece also had paintings on the outer side of the shutters, but these are lost.

40 There is no documentary evidence that Ansten Jonsson Skonk went to Bergen, but we know he travelled to an interregnum privy council at Bud some 250 kilometres further north along the coast in 1533, on behalf of the bishop in Hamar. DN, vol. 10, 711.

41 The presence of St Catherine and St Dorothy among the four saints closer to the Virgin is probably due to the two being the patron saints of the guild of the German merchants in Bergen. 42 Jean de Vincennes, Gertrude. Dame de Nivelles (Brussels and Paris: Editions Universitaires, 1954), 151. There were also a St Gertrude's chapel in Lübeck and Hamburg. All three are now 
Yet, if Skonk had encountered St Gertrude in Rostock or in other places in northern Germany or Denmark, she would have been depicted wearing the robes of a noblewoman and carrying a church model. In Ringsaker, however, St Gertrude is dressed according to the Brabantine pictorial tradition, as a Benedictine nun carrying a book and a crozier (Figure 6). This means that even if Skonk did request the saint to be included, he did not influence the actual fashioning of the sculpture. Instead, the carvers looked for representations of her in art produced in their own

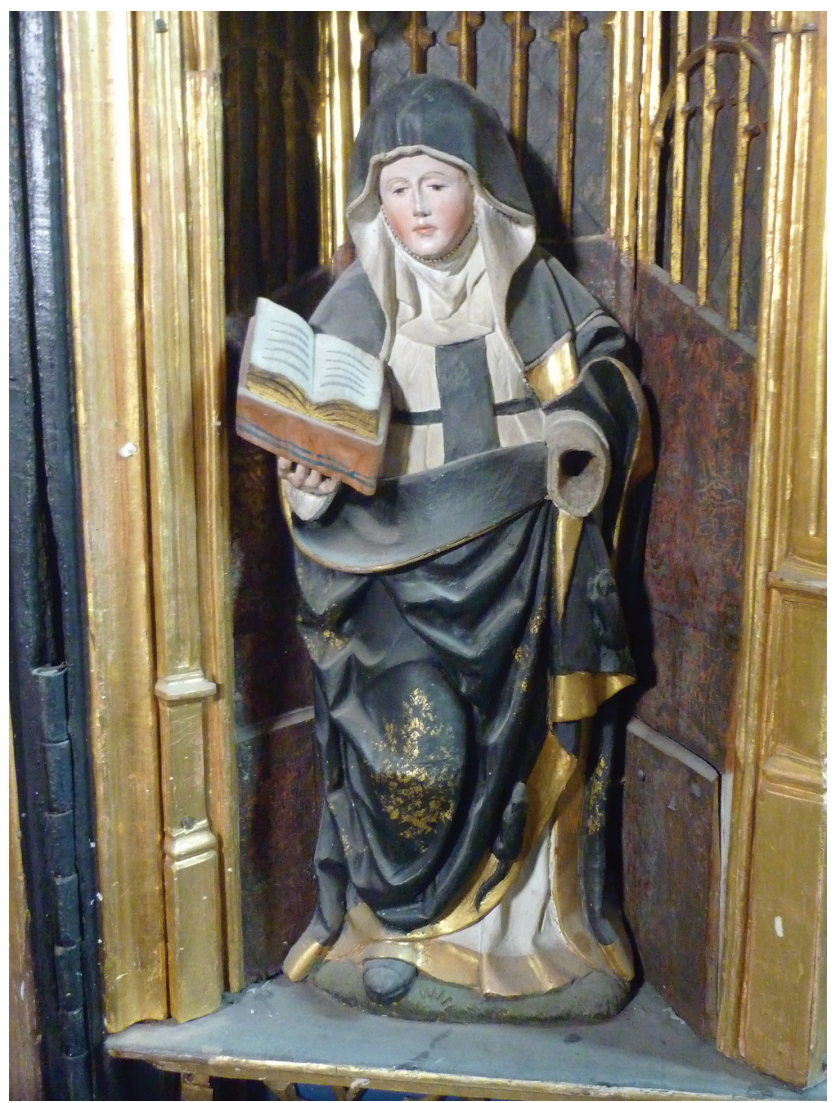

Figure 6: St Gertrude, detail from the altarpiece in Ringsaker (c. 1530). Photo: Ragnhild M. Bø

lost. St Gertrude became very popular in northern Germany in the fifteenth and sixteenth centuries as one of saints protecting against plague. 
artistic environment, for example in sculptures of the saint associated with the Brussels workshop of Jan Bormann II, such as the wooden sculpture in the church of St Gertrude in Etterbeek (c. 1490) (Figure 7) and the stone sculpture in the church of St Gertrude in Nivelles (c. 1520). ${ }^{43}$

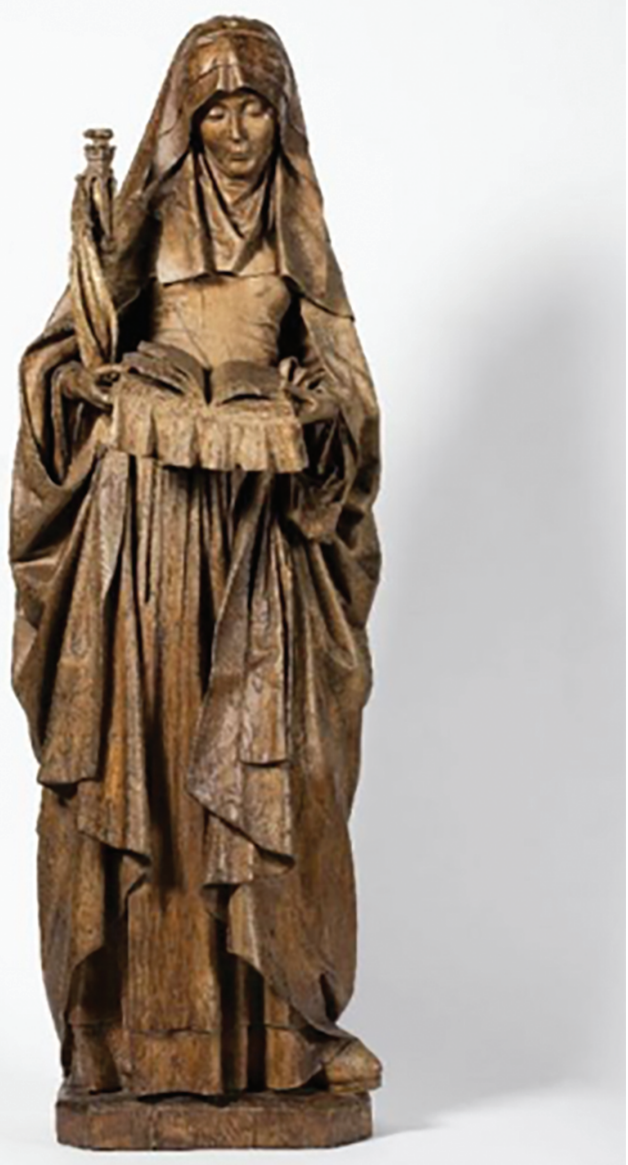

Figure 7: Circle of Jan Borman II (?), St Gertrude, oak with traces of polychromy church of St Gertrude, Etterbeek (c. 1490).

Photo: Katrien van Acker @ KIK-IRPA, Brussels

43 For the two sculptures, see Marjan Debaene, ed., Borman: A Family of Northern Renaissance Sculptures (London: Harvey Miller, 2019), 209 and 215. For the iconography of St Gertrude, see Mireille Madou, De heilige Gertrudis van Nijvel (Brussels: Palais der Academiën, 1975) and 
The altarpiece from Vaksala, Sweden, is an interesting parallel to the Ringsaker work. Dated 1505-1515 and the product of several artists, this altarpiece is one of very few other Antwerp pieces that have sculpted saints on the inner side of the shutters, among them the indigenous saints Sigfrid and Botvid. Vaksala thus testifies to the Antwerp workshops' ability to incorporate locally venerated saints in larger panoramas, catering to local, not necessarily personal, demands. Moreover, even if made approximately twenty years apart, Vaksala and Ringsaker also share the same painted subjects on the shutters. However, while the poses of the murdered St Ursula are very similar in these two altarpieces, the conceptualization of the death of the ten thousand martyrs differs considerably: in the Vaksala work they are crucified, and in the Ringsaker altarpiece they are impaled on thorns (Figures 8 and 9). These literary thorny details are included in the background of Dürer's woodcut of the motif from 1496. Similarly, the Beheading of St John the Baptist in Ringsaker seems to have been painted by an artist familiar with The Beheading of St John the Baptist by the Pseudo-Bles, a work widely copied and itself likely based on Albrecht Dürer's 1510 woodcut. ${ }^{44}$ Dürer's designs, however, may have been introduced on a larger scale to Antwerp painters only after his travels in the Netherlands in 1521, in time for the making of Ringsaker. The two altarpieces, however, evidence not only Antwerp workshops' ability to cater to local and/or personal demands, but also their willingness to do something new or different within the limits of decorum in previously crafted religious art, as was given due notice by Harbison.

At a later point in time, the altarpieces in Vaksala and Ringsaker would both be designated as beautiful. During the process of recording valuable heritage in Swedish churches, the so-called Rannsakningar efter antikviteter (1666-1693), Carolus Lithman (who would become Bishop of Strängnäs) wrote in 1669 that Vaksala possessed "a beautiful altarpiece," continuing by saying "that her equal

Ragnhild M. Bø, "Very Little, Almost Nothing: The Cult of Saint Gertrude of Nivelles and St Clare of Assisi in Late Medieval Norway," in The Cult of Saints in the Archbishopric of Nidaróss, ed. Ragnhild M. Bø and Jon Viðar Sigurðsson (Turnhout: Brepols, in press).

44 Dan Ewing, "The Beheading of Saint John the Baptist” in ExtravagAnt!, 56-58. Apart from Dürer's works circulating in prints and painted copies, uncommon features may have been caused by German or Swiss journeymen working in the Antwerp workshop around the time Ringsaker was made. One altarpiece displaying similar thorny deaths is the altarpiece painted in the workshop of Hans Leu for the Kappelerhof chapel in Zurich around 1509, see The Renaissance Nude, ed. Thomas Kren, Jill Burke, and Stephen J. Campbell (Los Angeles: Getty Publications, 2018), 284-285. A similar mix of German and Netherlandish features is also to be observed in the scene of the 10,000 martyrs included in what is now the right shutter of the altarpiece on the southern side of the main altar in Trondenes parish church. For features in the Antwerp altarpiece in Oxburgh Hall possibly betraying a German presence, see Woods, Imported Images, 149. 


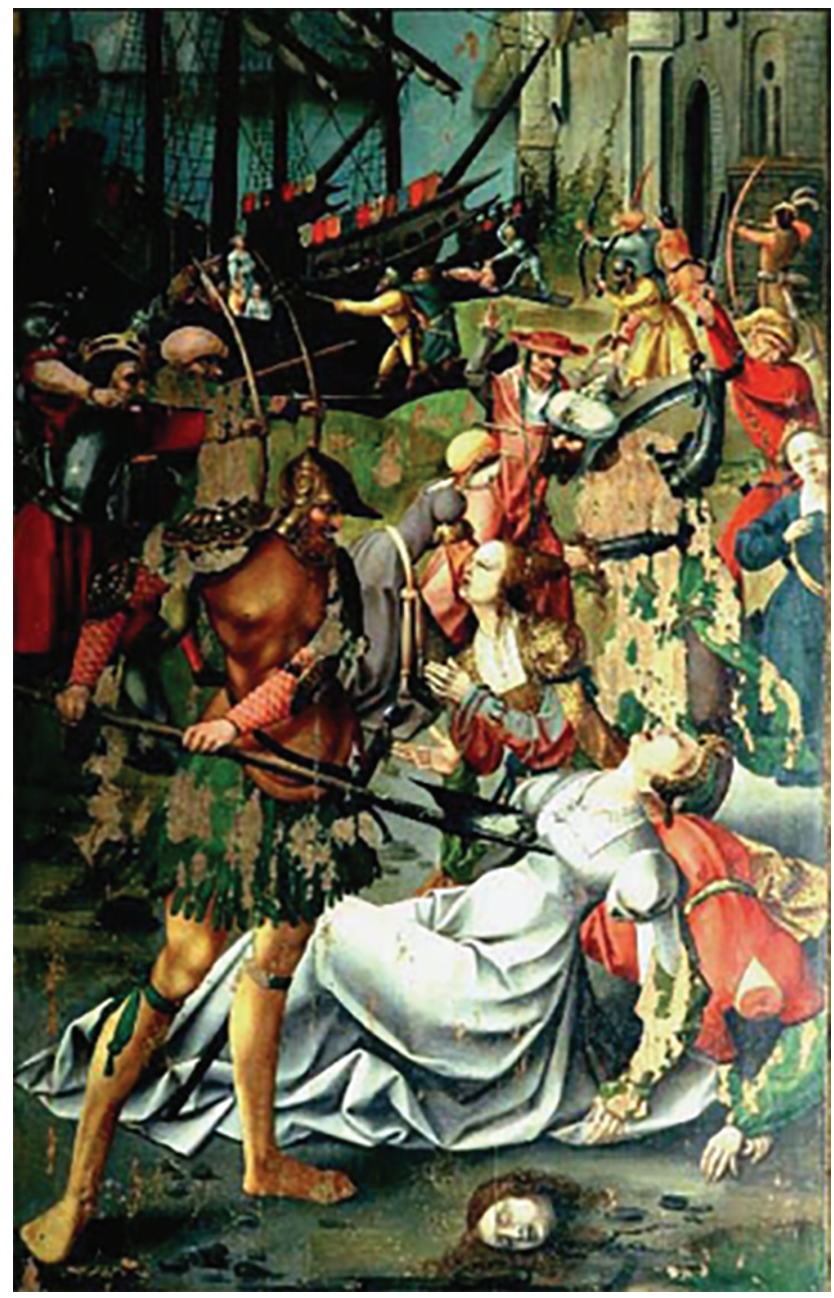

Figure 8: Antwerp altarpiece in Vaksala church (c. 1500-1525), the deaths of St Ursula and the 11,000 virgins and St Acacius and the 10,000 martyrs.

Photo: Lennart Karlsson @ Statens historiska museer

may not be found på landet." 45 This description is slightly ambiguous, however, as "på landet" may refer to "in the country," but also - and just as likely - to "on the

45 "een sköön Altaretaffla, att hennes lijke nappast skall finnas på landet,” cf. Carl Ivar Ståhle, Ingemar Olsson, and Nils-Gustaf Stahre, eds., Rannsakningar efter antikviteter: Uppland, Västmanland, Dalarna, Norrland, Finland (Stockholm: Kungliga Vitterhets Historie och Antikvitets Akademien, 1960), 12. 


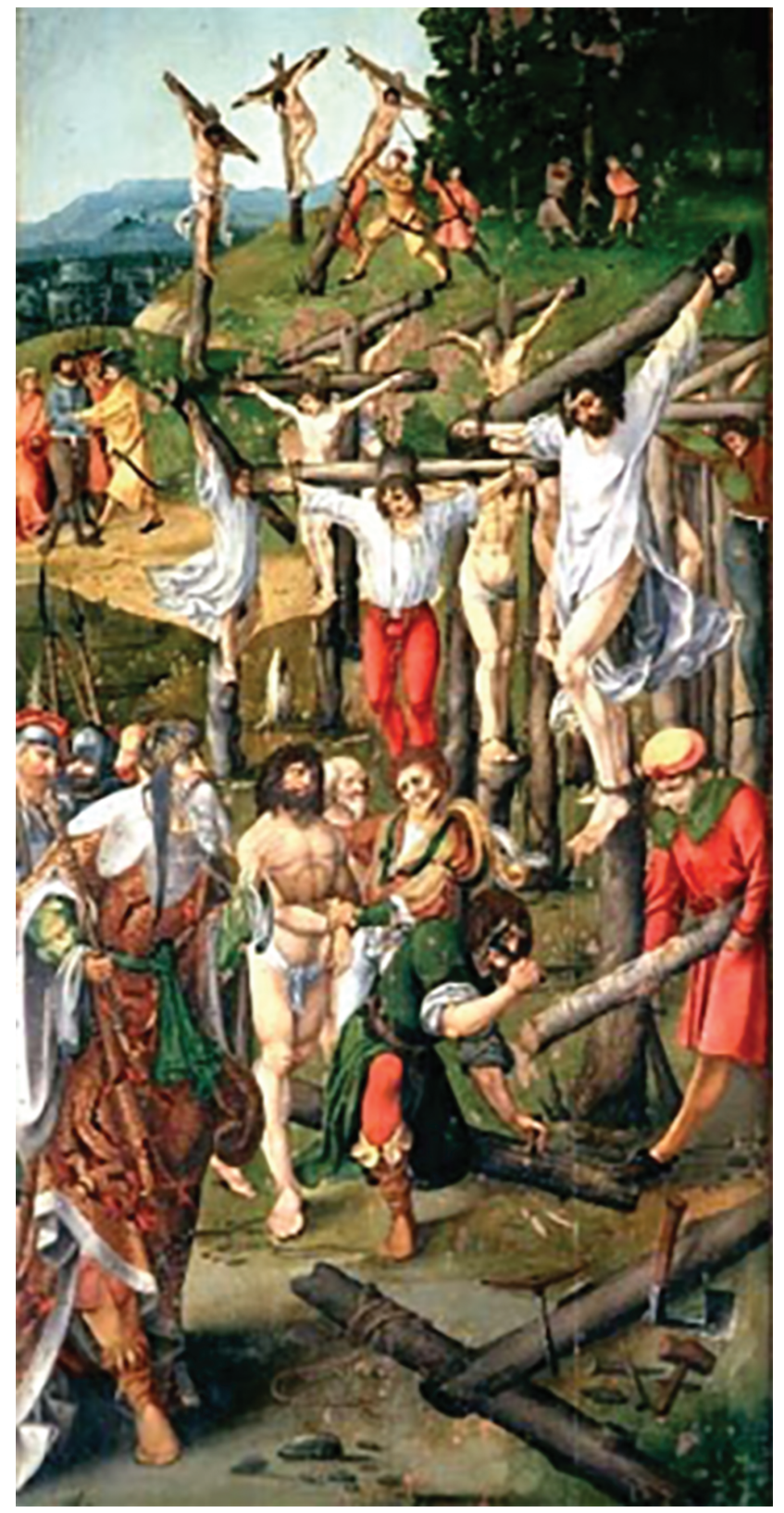

Figure 9: Antwerp altarpiece in Vaksala church (c. 1500-1525), the deaths of St Ursula and the 11,000 virgins and St Acacius and the 10,000 martyrs.

Photo: Lennart Karlsson @ Statens historiska museer 
countryside." The altarpiece in Vaksala was undoubtedly conceived of as beautiful, yet perhaps in regard to the fact that it was situated in a parish church, and not in a more prominent one, such as the nearby Uppsala cathedral. For Ringsaker, however, its beauty was of no doubt: As noted above, in 1594 Bishop Jens Nielsøn wrote that there was no altarpiece more beautiful in the whole of Norway.

When included in Antwerp altarpieces, the Jesse Tree is most commonly placed in the central compartment, allowing the stems to swirl and frame either the Crucifixion or the Apocalyptic Madonna. Given that the combination of iconography in the central corpus related both to the Virgin and to the Passion is rare in Antwerp altarpieces, the atypical Jesse Tree motif in Ringsaker may serve as further evidence of the role of the commissioner in determining the iconographic program of this work. Moreover, the combined Marian and Passion iconography in a single altarpiece could also be understood as an attempt to condense meaning into one work that was previously distributed throughout the church. In the medieval church interior, the Virgin would often have been present on a side altar; with the removal of these altars after the introduction of the Reformation, the retention of motifs related to the Virgin in an altarpiece with an outspoken Passion iconography could have delicately preserved her presence. ${ }^{46}$

If some of the altarpieces known to Skonk, such as the ones in Hamar Cathedral and St Hallvard, did influence his commission of an altarpiece for Ringsaker, they would not have provided a model for the inclusion of a sacramental tabernacle. ${ }^{47}$ In fact, very few altarpieces from the sixteenth century contain such tabernacles. Martin Wangsgaard Jürgensen has argued that this feature may have developed as a way of investing the altarpiece with the practical function similar to a sacramental tower or a sacramental cupboard, pointing to the altarpieces in Århus Cathedral (Lübeck, 1479) and in the parish churches of Østbirk (Lübeck, c. 1480) and Rom (unknown, 1520). ${ }^{48}$ Interestingly,

46 I am well aware there are Norwegian altar frontals from the thirteenth century with such combinational iconography. For these, for example Kaupanger, with a Coronation of the Virgin in the central scene, surrounded by miracles and/or martyrium of St Nicholas, St Andrew, St Peter, St Olaf and St Michael. Kaupanger was a small stave church possibly with one altar only. The combined iconography may thus have been a solution to address more saints in one piece. 47 The spacious central compartment of Onsøy is ambiguous. The Trinity (Throne of Mercy) does not quite fit in its place and may have been taken from another altarpiece. As there is ample space left, this allows for a hypothesis that there was once a sacramental tabernacle included below the sculpture.

48 Martin Wangsgaard Jürgensen, Ritual and Art Across the Danish Reformation. Changing Interiors of Village Churches 1450-1600 (Turnhout: Brepols, 2018), 358-64. For brief descriptions of the altarpieces, see Bruun and Plathe, Danmarks senmiddealderlige altertavler, 792-93 (Rom), 1237-40 (Østbirk) and 1276-84 (Århus). 


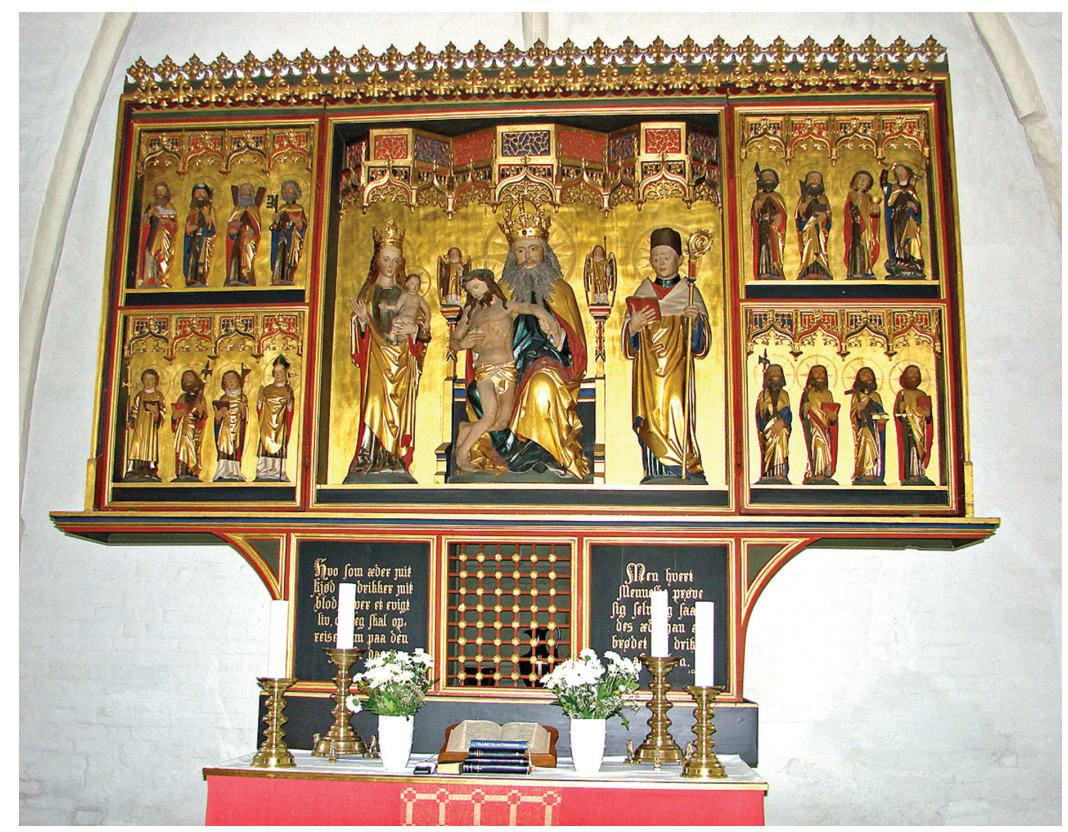

Figure 10: Lübeck altarpiece in Østbirk church (c. 1480), open position.

Photo: Jens Bruun

the ones in Østbirk (Figure 10) and Århus have doors of lattice work of the same variety found in the altarpiece in Ringsaker. ${ }^{49}$ These three Danish examples, however, have a niche inserted within the predella of the altarpiece rather than incorporated into the lower scene of the corpus. Furthermore, these niches are empty; they do not contain a Man of Sorrows and a chalice. ${ }^{50}$

Although the division of the architectural compartments in Ringsaker is identical to the other Antwerp altarpieces previously associated with Robert Moreau, the only Antwerp altarpiece with a niche of identical use to that of the Ringsaker - a niche with no narrative sculptural scene - is the one now in Oxburgh Hall. Because this altarpiece also has a nineteenth-century cupboard inserted below the niche, it is difficult to determine the function of the original

49 The altarpiece in Rom may have had similar doors which have not been preserved.

50 For Kirsten van Ausdall, function was inextricably linked to imagery as sacramental tabernacles "could serve two purposes: first, that of preservation of the consecrated Host and, second, a type of artistic ostension (...) helping the pious more completely envision the contents and thus achieve communion with Christ." See van Ausdall, "Communicating with the Eucharist," 473. It must be stressed here that this quote relates to freestanding tabernacles. The mix of function and aesthetic, however, may also apply for tabernacle niches in altarpieces. 
niche or if any sculptures were initially included (Figure 11$).{ }^{51}$ For the Ringsaker altarpiece, the situation is reversed: we do not know if the niche was actually used for the consecrated Host, owing to the amount of space occupied by the Man of Sorrows.

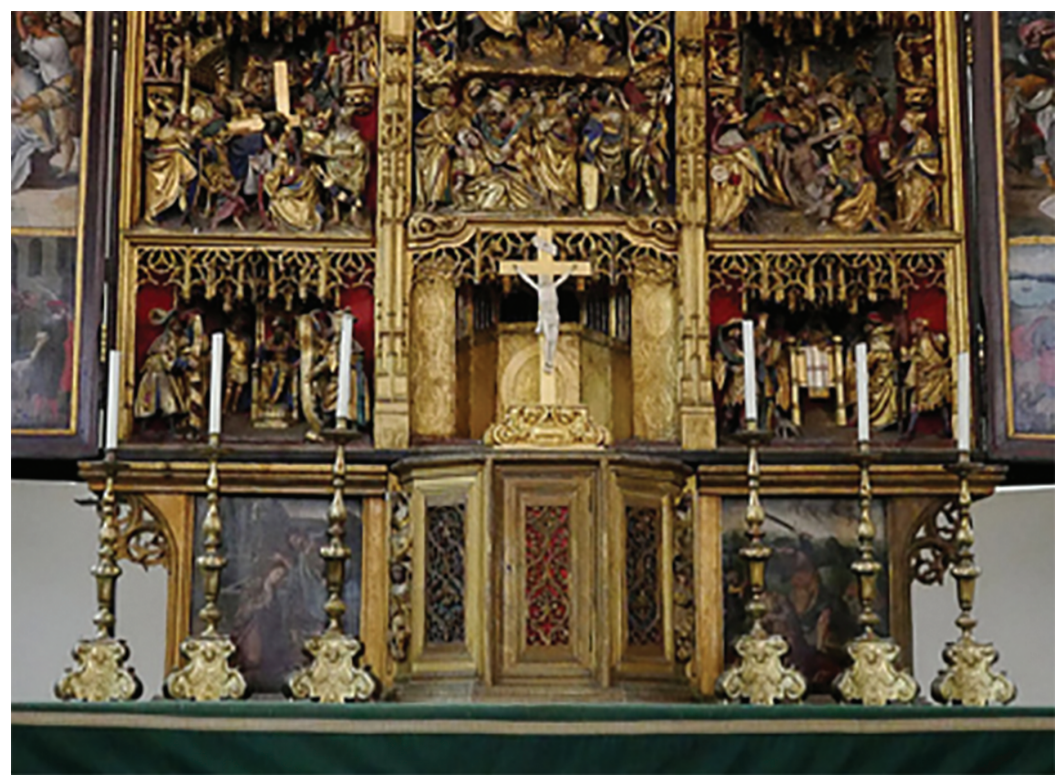

Figure 11: Antwerp altarpiece in Oxburgh Hall (1500-1530), open position, details. Photo: Yvonne Pay.

Thus, the sculptures in the wings and the choice of some of the saints in the Ringsaker altarpiece seem to be the result of Skonk's requests, while it seems that atypical and inventive motifs were decisions made in Antwerp, such as the paintings modelled on Dürer's designs featuring in the carving and painting of the motifs. The inclusion of St Olaf (the patron saint of Ringsaker) and St Hallvard (the patron saint of Oslo and Eastern Norway) would be expected, as would also the triple representation of St John the Baptist (the patron saint of Skonk). St Gertrude would perhaps not have been expected, but as she is not found in any other preserved Antwerp altarpiece, her presence seems nevertheless to have been

51 Woods, Imported Images, 455-65. 
requested by Skonk..$^{52}$ Because sacramental niches are indeed infrequent in late medieval altarpieces, the inclusion of the one in Ringsaker may have been included at Skonk's request, too.

However, the Man of Sorrows (Figure 12), either partly visible behind closed doors or vividly on display when the doors were open, echoes the possibilities to conceal and reveal the paintings and sculptures in a winged altarpiece such as this one. Moreover, the lattice work allows for a positioning of the Man of Sorrows in accord with Erasmus' outline of allegory as the point where understanding moves from the literal to the spiritual: "Sacred things display more majesty if they are brought to view under a veil than if they are laid bare just like that (...). We discover the truth more agreeably if it first has baffled us by the cover of enigma." 53 In the Ringsaker altarpiece, the beholder's precluded view of the Man of Sorrows and the possible enigma of meaning-making is balanced by an overall iconography seemingly geared towards visual engagements with the Eucharist. Some of the ways these engagements may have unfolded will be explored in the following sections.

\section{The carved scenes and the Eucharist}

Martin Wangsgaard Jürgensen has also suggested that the visual strategy behind an altarpiece is a concentric and hierarchic disposition of its iconographical content: from an epicentre, figures "radiate from the core motif as witnesses or scenes, testifying to the sanctity of the central motif." 54 Peripheral placement, however, does not negate the importance of such figures or scenes. Applying this argument to the altarpiece in Ringsaker, the Crucifixion, the Trinity and the Man of Sorrows in the central compartment clearly demonstrate the instrumental role of these motifs in popular devotion, imitational Passion and ocular communion. ${ }^{55}$ All of the individual scenes in the altarpiece then correspond to these central motifs; some

52 Deducing that St John the Baptist was Ansten Jonsson Skonk's patron saint is mostly based on the fact that the Baptist is the saint chosen to present the priest to the Trinity, although the saint may also be associated with the priest through the family name Jonsson.

53 Erasmus, Ratio verae theologiae as quoted and further explored in Michel Weemans, "Herri Met de Bles's Way to Calvary: A Silenic Landscape," Art History 32, no. 2 (2009): 307-31, at 308. 54 Wangsgaard Jürgensen, Ritual and Art, 364.

55 The literature on the Man of Sorrows and similar devotional images is extensive. For different yet poignant perspectives, see Alasdair A. MacDonald, Bernhard Ridderbos, and Rita M. Schlussemann, eds., The Broken Body: Passion Devotion in Late Medieval Culture (Groningen: Egbert Forsten, 1998). For ocular communion, see e.g. Suzannah Biernoff, Sight and Embodiment in the Middle Ages: Ocular Desires (London: Palgrave, 2002). 


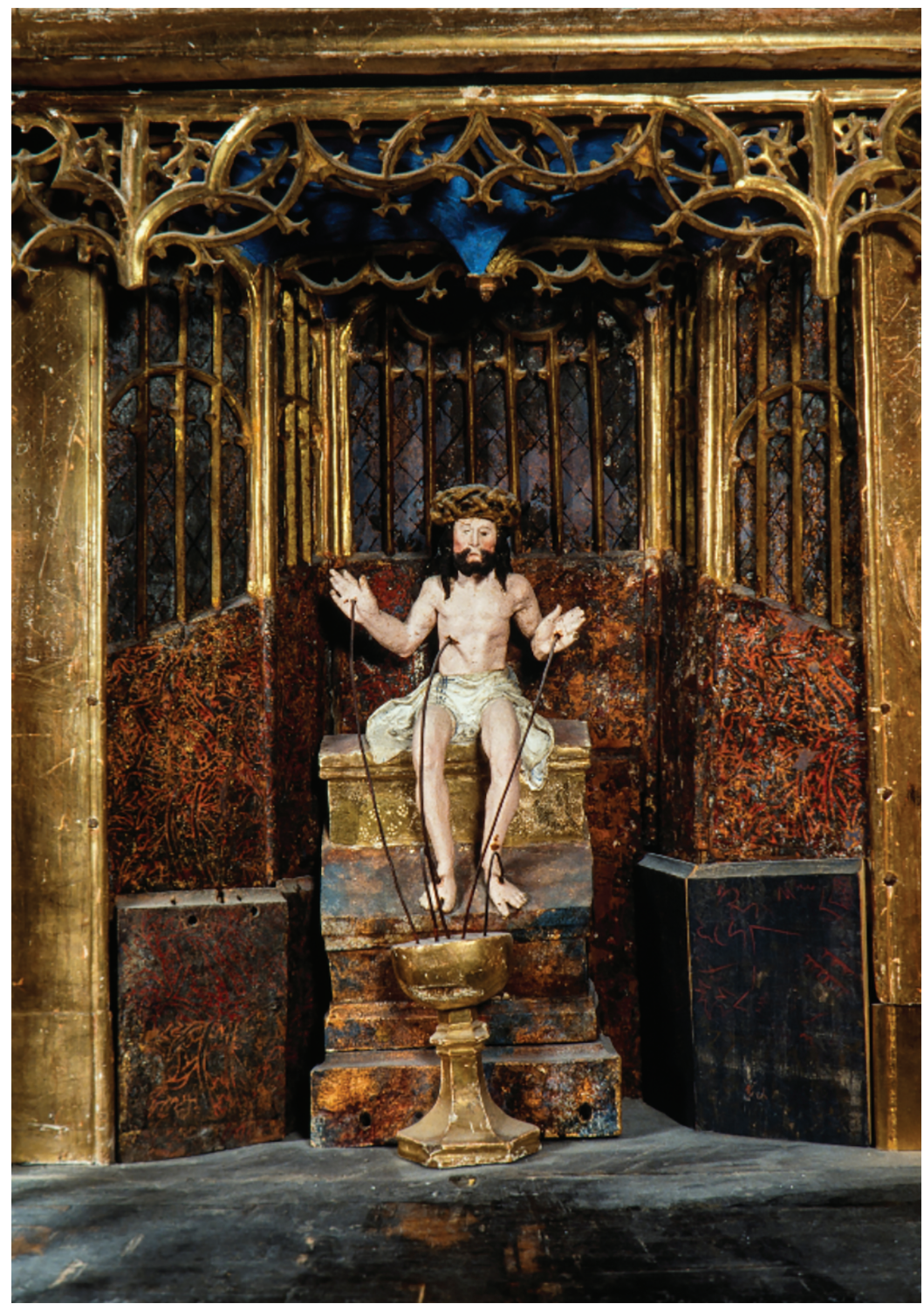

Figure 12: Christ as the Man of Sorrows, detail from the altarpiece in Ringsaker (c. 1530). Photo: Jan Haug (C) Anno Domkirkeodden

of them are readily associated with the Eucharist, and some enhance the core motifs in more subtle ways. For example, the Adoration of the Shepherds and the Adoration of the Magi - apart from visualizing the Nativity and the Epiphany, the 
celebrations of the Word Incarnate and its physical manifestation to the Gentiles both involve travelling towards a locus of truth. As such, late medieval parishioners may have understood these two scenes as allegories not only of pilgrimage, but of spiritual pilgrimage. Less concerned with spirituality and more with the lived religious experience, the kneeling positions of shepherds and kings mirror the kneeling position of the devout when receiving the Eucharist. The Three Magi could also serve as models for gift giving, not only in terms of devotional acts of giving things, but also in terms of performing charitable works. ${ }^{56}$

The other two "central side" niches, the Apocalyptic Madonna and the Arbor Annae, also complement the Eucharist theme. Presenting the Virgin as "a woman clothed with the sun, and the moon under her feet, and upon her head a crown of twelve stars," yet carrying Christ, the Apocalyptic Madonna in Ringsaker merges the motifs known individually as Theotokos (Mother of God), Regina Coeli (Queen of Heaven), Bride of Christ, Mary Immaculate and Ecclesia triumphant into one single image. ${ }^{57}$ Additionally, the rosary surrounding her and the five wounds included in the rosary were subject to indulgences equivalent to the many indulgences promised to those uttering prayers before the Man of Sorrows. ${ }^{58}$

The Arbor Annae motif features the visual connection between the Jesse Tree and Christ's suffering on the wooden Cross, which has its theological roots in the writings of Peter Damian (d. 1072), who introduced his homily De exaltatione Sanctae Crucis with the maxim "De virga Jesse devenimus ad virgam crucis, et principium redemptionis fine concludimus." 59 Increasingly popular in the Netherlands and Germany from the sixteenth century onwards, the Jesse Tree was understood to be a motif that linked Incarnation and Redemption. In Ringsaker, this motif is abridged: the prophets Isaiah and Jeremiah, with an angel in between them, display scrolls stating

56 Gift giving also included “(...) as well as individually in 'private' prayers, whether or not in conjunction with fast and the performance of 'good works' such as the distribution of alms and pittances and commemorative meals or 'refections' in order to ensure salvation," cf. Arnoud-Jan A. Bijsterveld, Do ut des: Gift Giving, Memoria and Conflict Management in the Medieval Low Countries (Hilversum: Verloren, 2007), 9-10.

57 Revelation 12: 1.

58 Although most of the motifs date back to earlier centuries, the indulgences developed in the fifteenth century. See the outlines in Sixten Ringbom, "Bild och avlat II. Smärtomannen, Rosenkransen och Jomfrun i solinne," ICO - Iconographisk post 4 (1979): 1-16 and Sixten Ringbom, Icon to Narrative: The Rise of the Dramatic Close-Up in Fifteenth Century Devotional Painting (Doornspijk: Davaco, 1984), 11-72. Also see Walter S. Gibson, "Prayers and Promises: The Interactive Indulgence Print in the Later Middle Ages," in Push Me, Pull You: Imaginative and Emotional Interaction in the Middle Ages and the Renaissance, ed. Sarah Blick and Laura Gelfand (Leiden: Brill, 2011), 277-324.

59 'Out of the 'virga' of Jesse we came to the 'virgam' of the cross and the beginning of redemption was the conclusion"; quoted in Green, Tree of Jesse, 144. 
Egredietur de radice Jesse virga, Stillabunt non and Creavit dominus, but the actual Jesse Tree is substituted with St Anne and Joachim. Stems grow from the chest of these two, meeting in a supreme flower carrying the Virgin and Child.

Although pushed even farther from the centre, two of the sculpted saints in the shutters, namely, St Nicholas and St Gertrude, may also be understood to complement the overall Eucharistic message. There may have been several reasons for their inclusion, but here I will address them as two out of three saints in the entourage who did not suffer a martyr's death and as the two sharing the attribute of the crozier. The juxtaposing of St Nicholas and St Gertrude may also have been the result of conflations of other associations between the two: both performed a miracle involving the rescue of endangered seafarers and travellers in general. Whereas St Nicholas is very often depicted restoring life to the slain three children - as in the Ringsaker altarpiece - and was the patron saint for a dozen different professions, he was more readily evoked by sailors, fishermen and merchants, while Gertrude tirelessly helped travellers, pilgrims and people suffering from illness throughout her lifetime. Their association with travellers, and pilgrims in particular, is emphasized in the altarpiece through their proximity to the Nativity and Epiphany, respectively. Thus, they are seemingly the only ones who do not emulate the Host by associations later developed by Lacan as corps morcelées, or fragmented bodies. ${ }^{60}$ However, it can be argued that these two saints allude to the Eucharist, through references to the chalice, rather than to the Host.

One of the miracles St Nicholas performed concerned a nobleman who wanted a son and promised that he would offer the saint a golden cup in return for the miracle. When the boy came of age, the father and son travelled to the church of St Nicholas to offer a newly made cup to the saint. But the first cup the father had commissioned pleased him so much that he kept it for himself, and thus now travelled with a second cup to be given to the saint. During the journey, the boy fell into the sea and disappeared but was saved by St Nicholas, and, in thanks, the father then offered both cups to the saint. ${ }^{61}$ This miracle inverses the more common connotation of St Nicholas as being someone

60 Julia Reinhard Lupton, Afterlives of the Saints: Hagiography, Typology, and Renaissance Literature (Stanford: Stanford University Press, 1996), 47-51. With no references to Lacan, Daria Dittemeyer also touches upon the associations between martyrs and the host, even if "Der Martyrerkörper hingegen erfährt keine wundersame Transformation, denn die Veränderung des Körpers und das Auftreten von Blut sind der Gewalt der Glaubensfeinde geschuldet"; they do, and in particular when displayed in great numbers, "dadurch zu lebenden Hostien erhoben.” Daria Dittmeyer, Gewalt und Heil: bildliche Inszenierungen von Passion und Martyrium im späten Mittelalter (Cologne: Böhlau, 2014), 143 and 145.

61 Cf. https://sourcebooks.fordham.edu/basis/goldenlegend/GoldenLegend-Volume2. asp\#Nicholas. 
who gives rather than receives, and as a result serves as an example of the devotional act of giving, for instance, through the donation of material items to a church.

In the original Latin, the cup in the story is referred to as a scyphus, a communion cup or chalice, underscoring for everyone hearing or reading the miracle how the act of bestowing such an item to a church would both please the saint in whose name the contribution was made, and facilitate further participation in the celebration of the Eucharist. None of the miracles associated with St Gertrude concern actual chalices, but as patroness of travellers, she was invoked in toasts people made before commencing their journey. ${ }^{62}$ In a time when parishioners themselves would not touch the chalice during the ritual of the Eucharist, toasts honouring saints may have served as a proxy sensorial experience of the chalice and the wine, even if toasting for one's safety during travels would never be equated with consuming Christ's blood. The two saints elegantly demonstrate the devout parishioner's ability to partake in empathic devotions, encouraged both to offer gifts to the church, to travel (to go on pilgrimage) and to involve oneself in the performance of the partly precluded ritual of the Eucharist. ${ }^{63}$ In the Ringsaker altarpiece, the person nearest the Eucharist motif and thus best able to partake in the ritual is Ansten Jonsson Skonk - a man whose coat of arms included a chalice, a leg and a lily.

\section{The painted scenes and plagues - and the Eucharist}

Whereas the sculpted martyrs on the inside of the shutters of the Ringsaker altarpiece are portrayed in a non-narrative mode, the brutality of martyrdom and references to disease are made insistently manifest on the outside painted panels. The left wing depicts the decapitation of St John the Baptist and the torture of St John the Evangelist in a cauldron of oil. ${ }^{64}$ The right wing presents

62 Lisa Hopkins, Shakespeare on the Edge: Border-Crossing in the Tragedies and the Henriad (Aldershot: Ashgate, 2005), 44-45.

63 For an exemplary outline of similar connections between celebrants and images in an Italian context, see Kirsten van Ausdall, "Communicating with the Host: Imagery and Eucharistic Contact in Late Medieval and Early Renaissance Italy,” in Push Me, Pull You, ed. Blick and Gelfand, 447-86.

64 Whereas the Beheading of St John the Baptist is based in Scripture (Matthew 14: 1-12; Mark 6: 14-29), the torture of St John the Evangelist has no canonical reference. The event may derive from the incomplete Acts of John, dated to 150-200 AD. 
the mass murder of St Acacius and the ten thousand martyred soldiers, above the equally distressing martyrdom of St Ursula and her eleven thousand virgins. In pictorial terms, the left wing features close-up depictions of the suffering bodies of John the Baptist and John the Evangelist, and these are juxtaposed with, on the right wing, representations of piles of mutilated bodies. Then in the predella below, the panels next to the four Church fathers offer images of St Sebastian and St Rochus. St Sebastian is tied to a tree, his executioner close by, torturing the saint's body with multiple arrows. St Rochus stands, displaying his plague bubo on his thigh in the company of an observant angel.

Plague iconography appeared in Christian art first after the Black Death. Christine M. Boeckl notes that the reason plagues were not previously depicted "can be in part explained by the fact that illness was not of universal interest before the advent of Humanism." 65 This attention to illness, combined with the enormous death tolls resulting from the Black Death, would certainly find resonance in motifs such as those of St Maurice and the Theban legion and the two motifs present in Ringsaker, St Acacius and the Martyrdom of the Ten Thousand and St Ursula and the eleven thousand virgins. ${ }^{66}$ Even if there was a shift in iconographical repertoires in the mid-fourteenth century accompanying new world views, there were many waves of plagues, resulting in fluid changes in the visual religious culture. The cults devoted to St Sebastian and St Rochus, and thus also visual depictions of the two, became popular in Italy only after the outbreak of the plague in $1470 .^{67}$ The two saints became much beloved Pestheilige, as did St Gertrude and the Fourteen Holy Helpers. St Sebastian and St Rochus are present in Ringsaker when the altarpiece is closed - that is, on most days of the week - and they may have actively contributed as intercessors against pestilence and sudden death. ${ }^{68}$

There are at least two further examples of Antwerp altarpieces with St Sebastian and St Rochus. In the altarpiece at Västra Ingelstad (1525-30), the

65 Christine M. Boeckl, “Giorgio Vasari’s 'San Rocco Altarpiece': Tradition and Innovation in Plague Iconography,” Artibus et Historiae 22, no. 43 (2001): 29-40, at 29.

66 Dittmeyer, Gewalt und Heil, 133. She erroneously argues for Acacius and Ursula being included among saints widely venerated as the Fourteen Holy Helpers; they were not.

67 Louise Marshall, "Manipulating the Sacred: Image and Plague in Renaissance Italy," Renaissance Quarterly 47, no. 3 (1994): 485-532.

68 If Skonk was familiar with St Gertrude from Rostock, he may also have encountered St Rochus in that city, yet not the St Rochus altarpiece in St Mary, as this was only made around 1530. See Kathrin Wagner, "The High-Altarpieces in the Hanseatic City of Rostock in Northern Germany: A Hagiographic Approach to the Creation of Collective Identities," in Cuius Patrocinio Tota Gaudet Regio: Saints' Cults and the Dynamics of Regional Cohesion, ed. Stanislava Kuzmová et al. (Zagreb: Hagioteca, 2014), 285-96. 
two are painted in tandem on the exterior part of the wings, with St Sebastian curiously dressed as a contemporary knight. In a triptych made between 153040, they are positioned on the inside, on either side of the Adoration of the Magi. According to Niklas Gliesmann, this triptych is stylistically singular within the group of preserved small-scale Antwerp altarpieces, as the sculptural style resembles the much larger Oplinter altarpiece. As it is, the Oplinter piece is often referred to as the quintessential Robert Moreau altarpiece, one of the altarpieces which is thought to have influenced the one in Ringsaker. ${ }^{69}$ It therefore seems safe to assume that all three works were carved in similar artistic milieus in Antwerp, again as partly adhering to pictorial tradition and partly inventing the religious decorum, and that the cults of St Rochus and St Sebastian were acknowledged or perhaps even en vogue in the 1530s.

Representation of the Martyrdom of the Ten Thousand took on different guises: one solution presents the martyrs meeting their death through crucifixion or being impaled on thorny/spiked bushes, inviting inevitable Christological comparisons. ${ }^{70}$ Considering that the scenes of the multitude of bodies in the Ringsaker altarpiece would have encouraged parishioners to pray for help against the plague, the paintings may also be understood to reference the Eucharist. In particular, the blood gushing from the neck of the decapitated St John the Baptist mirrors the blood spurting from Christ as the Man of Sorrows in the interior niche. This link between the head of John the Baptist and the crucified Saviour is most famously stated in the York Breviary: "Caput Johannis in disco: signat corpus Christi qui pascimur in sancto altari, et quod ecclesie gentium tribuitur in salute ac remedium animarum."71 Moreover, the multivalence of the naked bodies found in the outer panels and their relation to Christ's naked body are aptly summarized by Daria Dittmeyer: "Der nackte Körper (...) ist Träger eines Heilversprechens, das durch das Martyrium und die Darstellung der gepeinigten, vielfach entblößten Körper der Märtyrer bestätigt und erneuert wird."72

69 Paris, Cluny Inv. no. 202, cf. Niklas Gliesmann, Geschnitzte Kleinformatige Retabel aus Antwerpener, Brüsseler und Mechelener Produktion des 15. und 16. Jahrhunderts: Herstellung, Form, Funktion (Petersberg: Michael Imhof Verlag, 2008), 221-22.

70 Stephen J. Campbell, “Unruly Bodies: The Uncanny, the Abject, the Excessive," in The Renaissance Nude, ed. Kren, Burke, and Campbell, 269-81.

71 "John's head on a tray signifies Christ's body, from which we eat at the holy altar. And which was given to the congregation of nations in salvation and remedy of souls," cf. Miri Rubin, Corpus Christi: The Eucharist in Late Medieval Culture (Cambridge: Cambridge Univeristy Press, 1991), 315.

72 Dittmeyer, Gewalt und Heil, 194. 


\section{Saints as witnesses, saints as words}

In the same manner in which altarpieces relate to other altarpieces, they also inevitably - relate to non-visual culture, to the words, sounds and rituals performed in their vicinity. Thus, the works may have been the product of the artists' and commissioner's knowledge of artefacts, as well as their intellectual engagement with the conceptualization of doctrines and faith. Returning to Martin Wangsgaard Jürgensen's suggestion that images in altarpieces were placed according to concentric hierarchies, the oft-repeated verse from St Paul's Epistle to the Hebrews (Hebr 12:1-5) is informative:

And therefore we also having so great a cloud of witnesses over our head, laying aside every weight and sin which surrounds us, let us run by patience to the fight proposed to us: Looking on Jesus, the author and finisher of faith, who having joy set before him, endured the cross, despising the shame, and now sitteth on the right hand of the throne of God. For think diligently upon him that endured such opposition from sinners against himself; that you be not wearied, fainting in your minds.

In the Ringsaker altarpiece, Christ as the Man of Sorrows - the author and finisher of faith - is placed centre stage, and the saints in the wings, along with Ansten Jonsson Skonk, are a cloud of witnesses to His sacrifice for the redemption of humanity.

The cloud of witnesses was a common trope in the late medieval cult of saints, found in the formula of the litanies and in the formulas for prayers and indulgences. ${ }^{73}$ Whereas some late medieval prayers are addressed to Christ alone, often envisioning the suffering of Christ on the Cross, ${ }^{74}$ others address multitudes of saints in patterns similar to the Monday and Saturday prayers found in a late medieval Danish prayer book:

On Mondays one should contemplate all one's serious sins and one should honour St Michael and all Holy Angels, St Cosma and Damian, St Christopher, St Nicholas, St Martin, St Gregor, St Eusebius and St Silvester. ${ }^{75}$

73 As there are no preserved prayer books from late medieval Norway, the following paragraphs apply Danish and Swedish prayer books as analogous to what may have been used in Norway.

74 "O, Lord Jesus Christ, I pray to you hanging on the Cross and carrying Your crown of thorns (...)." "O härra iehsu christe, jak bidher til tik hänghiande wppa korseno oc a thino hoffde thorn kronona bärenade (...)," cf. Robert Geete, Svenska böner från medeltiden efter gamla handskrifter (Stockholm: Kungliga boktryckeriet and Norstedt \& Söner, 1909), 112.

75 Copenhagen, KB, MS AM 784 4‥ "Om mandaghen skal man betencke alle sine sware syndher ock skal man hedre sanctum Mickel ock alle hellighe engle, sanctum Cosmam et daminum, sanctum Cristoferum, sanctum Nicolaum, sanctum Martinum, sanctum Gregorium, sanctum Ewsidium ock 
On Saturdays one should contemplate the joy of heaven and honour the Virgin Mary and all virgins, St Catherine, St Barbara St Dorothy, St Margaret, St Gertrude, St Agatha, St Otilia, St Apolonia, St Clare, St Cecilia, St Tecla, St Concordia, St Petronilla, the 11,000 Virgins pray for us eternally. Amen. ${ }^{76}$

Both of these prayers demonstrate that several saints are addressed when the devotee is asked to contemplate his/her sins and the joy of heaven. For both days, there are (no one-to-one) correspondences between the saints mentioned and the iconography in Ringsaker.

Prayers were to be said both privately and communally when attending Mass. Most prayers for the laity would be elevation prayers, that is prayers that encouraged an inner meditation of the Passion, linked to the sacring and seeing of the Host. According to English sources, the Sunday Mass included the bidding of bedes, that is prayers for a wide range of the gentry and clergy; but also for the parishioners, and those in special need, such as travellers, pilgrims, prisoners and pregnant women. ${ }^{77}$ The saints offering protection for these people in special need all figure in the Ringsaker altarpiece in its open position: St Nicholas and St Gertrude (travellers and pilgrims), St Barbara (prisoners) and St Margaret (pregnant women, childbirth). Other prayers not restricted to the Sunday Mass were said for the delivery of sudden or unprepared death, as in the case of death by plague, references to which are visually manifested in the altarpiece via the inclusion of St Catherine and St Christopher, when open, and St Sebastian and St Rochus, when closed.

One prayer in Ingeborg Predbjørnsdatter's (d. 1542) prayer book reads: "For pestilence and sudden death protect me (...) saintly knight George and St Sebastian the holy man and dear martyr and father saint Christopher (...)."78

sanctum Siluestrum,” cf. Karl Martin Nielsen, ed., Middelalderens danske bønnebøger, 5 vols. (Copenhagen: Det danske sprog- og litteraturselskap and Gyldendal, 1946-1982), vol. 4, 377.

76 "Om løffuerdaghen skal man tencke paa hemerigis glede ock ere iomfru Maria meth alle hellige iomfruer, sanctam Katherinam, sanctam Barbaram, sacntam Doroteam, sanctam Margaretam, sanctam Gertrudem, sanctam Agatam, sanctam Otiliam, sanctam Appoloniam, sanctam Claram, sanctam Ceciliam, sanctam Teclam, sanctam Concordiam, sanctam Pertronillam, the xi twsende iomfruer bede for oss ewindelig. Amen," cf. Middelalderens danske bønnebøger, vol. 4, 377.

77 Eamon Duffy, The Stripping of the Altars: Traditional Religion in England 1400-1580 (New Haven and London: Yale University Press), 90-131, in particular 123-25. There is no immediate match with the Missale Nidrosiensis, but as this applied to the whole archbishopric, regional differences and local traditions may have included similar practices.

78 "For pestilencie oc bradødh *beskerme ten som megh hawer skapt med myth syn egen mag toc krafft, o gode veluellige ihesu criste loff heder oc ere vare tegh, tw hawer beuaret megh i thenne nath* fremdeles y tyn nade oc barmherteghet ville vyde megh thenne til kommendis dagh fram ath læwe meth ydmighet oc I reth tro oc en stadig hob oc folkommeleg kerleghet til 
There are also other prayers that enlist even more saints in this endeavour: "These holy persons are to be honoured against pestilence Jesus, St Mary, St Anne, St Sebastian, St Silvester, St Martin, St Adrian, St Nicholas, St Christopher, St Rochus, St Bernardus, St Anthony." aging the devotee to pray to these saints each day because of their holiness, for example against pestilence and sudden death. ${ }^{80}$

Whereas several prayers in the corpus of late medieval devotional literature evoke the widely popular saints John the Baptist and John the Evangelist, there are also prayers that address the other martyrs depicted on the shutters in Ringsaker. One prayer from Sweden encourages the devout to honour the ten thousand martyrs every day by saying a Pater Noster and a prayer destined to these knights of Christ, "the ones chosen by Thee given the crown of martyrdom and flaming hearts." 81 St Ursula was invoked in order to "keep me from all cardinal sins, and the temptations of the devil, from shame and gander and all bothering talk, and sudden death and all evil." 82 St Ursula had the power to protect the devout both from the heavy burden of potentially committing a cardinal sin as well as from the more trivial unpleasantness.

theg, ath myn tienest motte vorde tegh behaffewelegh; thet vnde megh gwdh fader søn oc then hellegandh formedels iomfrv Maria bøn skwl oc rider sancta Iorgen oc sante Sebastiane then hellighe mantz oc gode martir oc fader sancta Cristoffers oct w verdige fader sancta Iheronime beskerme meg fra pestilencie oc bradød oc bedher for meg hath iegh motthe kome tyl then ewighe glede. Amen," cf. Middelalderens danske bønnebøger, vol. 4, 142.

79 "Tesse hellighen skall mand ere for pestilentie Ihesus, Sancta Maria, Sancta Anna, Sanctus Sebastianus, Sanctus Silvester, Martinus, Adrianus, Nicolaus, Cristoferus, Rochus, Bernardus, Anthonius IV,” cf. Middelalderens danske bønnebøger, vol. 4, 442.

80 "Tesse naffn skall mand neffne hwer dag, och bedh them for theris hellighe naffn skyld och for theris krafft och macht Som thy haffwe aff gudh ath the beware teg then dag och then nacth fra then plawe some er pestilentie och bradh dødh och aff alt annet wnth i naffn gud faders och søns och then helligandz," cf. Middelalderens danske bønnebøger, vol. 4, 442.

81 "Här äpther staar en godh bön aff X M riddara hedra them gärna hwar dag mädh pater nosterLoff wari tik min härra ihesus christus fför alla thina maktogha gärninga alt that skapadh är loffue tik oc take fför than säls skaran x M riddara som thu wtwakde Oc them gaff martyria krono Oc thera hiärta giordhe brännande, aff thäs hälga anda elde Swa at the haffdo wilia til at tiäne tik mädh liff oc siäl $\mathrm{O}$ ärofwlle härra x M riddara wtwalda martyres Christi riddara I ären riddara aff hwilkom skrifpthen sigher, at (I) prydhe ären mädh allom dygdhom, manlike $j$ örlöghe orädde för gudz owenom Oc gladhi til athola margfalla pinor J waren staddogha $j$ tronne Thwloghe $\mathrm{j}$ mothegangh, diärfe $\mathrm{j}$ sanindinne, som starkasta kämpa $\mathrm{j}$ hardhasta stridh oc bitherlikasta kropsens (korsens) pino,” cf. Geete, Svenska böner, 374.

82 “(...) oc beware mik fför allom dödhelikom syndom, oc diäffwlsens frestilsom fför skam oc bligh Oc alle lastelike wmthalan, aff bradhom dödh oc allo ondo (...),” cf. Geete, Svenska böner, 435-36. 
In the same manner as there exist correlations between written and visual evidence of the cults of saints, for example between prayers and altarpieces, there are also correlations between indulgence letters and altarpieces. Just as some images such as the Man of Sorrows and the Vera Icon were invested with indulgences, some altarpieces were fashioned as Ablass-Tafeln. The altarpiece in Ringsaker is not, however, an indulgenced image or an Ablass-Tafel, because there is no written indulgence attached to it. ${ }^{83}$ Nevertheless, comparing the iconography of the altarpiece with a long-standing indulgence from the fifteenth century is revealing. In 1407, Pope Gregory XIV granted forty days of indulgence to anyone visiting St Gertrude's chapel in Køge in Denmark ${ }^{84}$ and this indulgence was repeated by the Bishop of Roskilde the following year. ${ }^{85}$ In 1466, the indulgence was also proclaimed in Norway as the Archbishop Olaf of Nidaros bestowed forty days of indulgence for every devout who visited and made contributions to the church of St Nicholas and the chapel of St Gertrude in Køge.

In theory, at least, this letter (or similar letters now lost) should have been known to the congregation in Ringsaker. The indulgence was obtained if visiting the church and the chapel on certain days, specifically on Christmas Day, the Epiphany and the Corpus Christi, and the feast days of St Gertrude, St Catherine, St Barbara, St Dorothy, St Margaret and the Eleven Thousand Virgins. ${ }^{86}$ And these are the same feast days that are visualised in the lower main compartment as the Nativity, the Man of Sorrows and the Adoration of the Magi, together with the right shutter in the Ringsaker altarpiece. Moreover, St Nicholas and St Gertrude, the patron saints of the church and chapel in the indulgence, are placed on either side of the Nativity and Adoration of the Magi, one of the prime symbolic representations of gift-giving.

I do not argue that the Ringsaker altarpiece is fashioned according to specific prayers or indulgence letters, but that the ensemble of saints and feast days may have had their followers in the congregation, in particular the saints venerated with full feast days and those invoked against sudden or unprepared death. The saints present in the shutters of the altarpiece would have served as witnesses both to the joys of the Virgin and the suffering of Christ present in the altarpiece as well as to the devotional activities performed by the clergy and members of the congregation in the choir and the nave. Among these activities

83 On indulgenced images, see note 52 above. On altarpieces and indulgences, see Amy M. Morris, “Art and Advertising: Late Medieval Altarpieces in Germany," in Push Me, Pull You, ed. Blick and Gelfand, 325-45.

84 https://diplomatarium.dk/dokument/14070415001.

85 The indulgence was offered by the Bishop of Hólar (Iceland), Pétur Nikulásson (d. 1411), in the confidence of the Bishop of Roskilde, Peder Jensen Lodehat (d. 1416), cf. http://diplomata rium.dk/dokument/14080704001.

86 DN, vol. 2, 862. 
would have been prayers to the saints present as well as donations and charitable works in their name, possibly encouraged by indulgence letters. ${ }^{87}$ It thus seems likely to assume that the Ringsaker altarpiece is a manifestation of artists' and the commissioner's intellectual engagements with the conceptualization of doctrines and faith in a tangible object in the material world.

The connections between the Mass, the priests, the saints and members of the congregation would gradually disappear with the instalment of the Reformation, when saints lost their role as intercessors. This is most evident in the inscription added above the head of Ansten Jonsson Skonk, which states that God will pray for his soul. From a theological point of view, this is a most bizarre request; it is most likely a local, Lutheran attempt to avoid asking saints to pray for Skonk's soul, while also exempting members of the congregation a task that would have been theirs at the time the altarpiece was installed in the church.

\section{Surface, interior and the Eucharist after the Reformation}

As noted in the introduction, the Ringsaker altarpiece has remained in situ for nearly five hundred years, thus surviving relatively unscathed all postReformation religiously motivated changes in liturgical celebrations and nonreligious changes in aesthetics and perceptions. Various records and practices in Norway and elsewhere in northern Europe provide evidence of how and why artistic enterprises have survived. ${ }^{88}$ In Norway, there were apparently no happy hammers, no iconoclastic desire, no Second Royal Injunction of Henry VIII. Upon the arrival of the Reformation, however, a manual - the Church Ordinance - was composed to guide the superintendents and ministers in exercising their authority correctly. There is not much to glean from the Church Ordinance concerning the function of images, but as the ministers were urged not to "hatefully attack the papists unless he needs to do so in order to exhort and to set examples," it seems the wilful destruction of images

87 Indulgences were also attached to the hearing of certain texts from the Bible, such as the fourteen verses from the Gospel of St John read during Sunday Mass, cf. Duffy, The Stripping of the Altars, 124.

88 Many publications concerning the presence of medieval artefacts in Lutheran churches appeared slightly before and during the Lutherjahr in 1517, see for example The Myth of the Reformation, ed. Peter Opitz (Göttingen: Vandenhoeck \& Ruprecht, 2011) and the articles in the special issue "Changing Senses of Sacrality: Objects, Beliefs, and Performances from the Medieval to the Early Modern Era," Mirator 19, no. 1 (2018). 
may not have been encouraged during sermons. ${ }^{89}$ In Denmark, the Assumption of the Virgin in the altarpiece in Viborg was overpainted, as were the wings of the altarpiece in Holsterbro.

When the side altars were removed in the sixteenth century, some altarpieces and sculptures turned out to be redundant. The superintendent Peder Palladius suggested these be hung on a wall, unless they had been subject to cultic practices, in which case they had to be removed and burned. ${ }^{90}$ Both Palladius and the Church Ordinance seem to have been confident that people would know the difference between the right and wrong uses of an image, possibly because of what has become a frequently quoted section of Luther's “Confession Concerning Christ's Supper," from 1528, announcing all kinds of church ornaments as things indifferent. ${ }^{91}$ Scholars have suggested that "most communities adopting a Lutheran liturgy translated medieval Christian material culture to Lutheran use."92 Yet, when the Danish State Counsellor Jørgen Lykke and his entourage visited Bergen, Oslo, Skien and Trondheim in 1567, they observed a number of idolatrous practices. ${ }^{93}$ Thus Lutheran use occasionally also included non-Lutheran practices, even decades after the Reformation. There are, however, no records of such wrongdoings in Ringsaker.

Regarding Antwerp altarpieces in general and their role in post-Reformation societies, Susan Green has proposed that production of them in the sixteenth century came to reflect changing ideas regarding the use of religious imagery. As an example, she suggests that the relatively small scale of the sculpted parts of Antwerp altarpieces may have been considered less controversial during a time of religious upheaval, compared to the several life-size statues often contained in German altarpieces. Green further notes that "the extensive use of gold within the caisse meant that the miniaturized images could not be perceived of as real

89 Kirkeordinansen av 1537. Danmark-Norges kirkelov, trans. Terje Ellingsen (Oslo: Verbum, 1990), 48. Whereas the liturgy - the celebration of mass, that is - changed almost instantly, the material reordering of the church interior and the liturgical paraphernalia was a more gradual process.

90 Kåre Støylen, ed., Peder Palladius’ Visitasbok (Oslo: Forlaget Johan Grundt Tanum, 1945), 33. 91 "Images, bells, eucharistic vestments, church ornaments, altar lights and the like I regard as things indifferent. Anyone who wishes may omit them. Images or pictures taken from the scripture and from good histories, however, I consider very useful yet indifferent and optional. I have no sympathy with the iconoclasts," cf. Lee Palmer Wandel, The Eucharist in the Reformation (Cambridge: Cambridge University Press, 2006), 105.

92 Wandel, The Eucharist, 120.

93 Bente Lavold, "Holdninger til katolske altertavler etter reformasjonen," in Mellom Gud og Djævelen. Religiøse og magiske verdensbilleder i Norden 1500-1800, ed. Hanne Sanders (Copenhagen: Nordisk ministerråd, 2001), 155-76, at 156. The most famous example of so-called papistic activities in Norway is the cult devoted to the crucifix in Røldal stave church. 
and, with the inclusion of typological motifs (...) there was no danger of them being misconstrued."94 Typological motifs would include the Arbor Annae as an abridged Jesse Tree and the Apocalyptic Madonna, both found in the altarpiece in Ringsaker.

Further reasons for the endurance of altarpieces and other works of art may be linked to the commissioners' presence, their monetary value or the skills of the artists. Analysing the fate of the sacrament shrine of St Lorentz in Nuremberg, Lee Palmer Wandel posited that its survival resulted from one or more of the following alternatives: "Perhaps it survived because its donor was the City Council or Hans Imhoff the Elder (...); perhaps it survived because it was so valuable, having cost seven hundred Gulden and taken three years to complete; perhaps it survived because it was exemplary of the skill of Adam Kraft (...)." 95 The altarpiece in Ringsaker possibly possessed analogous appreciated features. It may have been preserved as a representative of Skonk's engagement in the congregation or it may have been preserved because of its Antwerp origin. It holds for both reasons that at crucial moments the altarpiece's status as a gift or its aura of Antwerp luxury goods must have been considered more advantageous than its iconographical program was considered papist and unworthy of adorning a Lutheran church interior. ${ }^{96}$

Luther insisted that God can be present in various ways, comparable to how vision allows the simultaneous perception of things near and far, or how it's possible to hear several sounds at the same time. For Luther, as for the Catholic Church, the Host was Christ's body and there was a real presence of Christ in the Eucharist. Nevertheless, the presence was recognised not in the sense of the bread and wine becoming the actual body and blood of Christ (transubstantiatio), but in the way the body and blood of Christ were present as appearances (forma) of bread and wine, the two preserving their own substance (consubstantiatio). ${ }^{97}$ If Christ is still present in the Eucharist, yet in the appearance of bread and wine instead of as transubstantiated body and blood, the Man of Sorrows in

94 Green, Tree of Jesse, 141-63.

95 Wandel, The Eucharist, 132. For similar questions and conclusions relating to art as adiaphora, also see Caroline Walker Bynum, “Are Things 'Indifferent'? How Objects Change Our understanding of Religious History, German History 34, no. 1 (2016): 88-112.

96 Also see the Swedish examples of preserved altarpieces in De Moor, "Moving altarpieces." 97 Lutheran Eucharistic theology is extensively treated by various scholars. See for example Wolfgang Schwab, Entwicklung und Gestalt der Sakramententheologie bei Martin Luther (Bern: Peter Lang, 1977) and Thomas J. Davis, “'The Truth of the Divine Words': Luther's Sermons on the Eucharist, 1521-1528, and the Structure of Eucharistic Meaning," The Sixteenth Century Journal 30, no. 2 (1999): 323-42. 
the niche remains as theologically permissible after the Reformation as it was in the late medieval period.

With the change in the celebration of Mass and the Eucharist after 1537, the previous conflation of the consecrated Host elevated by the priest and the Man of Sorrows and chalice in the Ringsaker altarpiece ceased. However, even if the previous hoc est enim corpus meum was now to be uttered as dette er mit legeme, and even if there were no link between Christ's body and the material world, these words were never spoken in a vacuum. Rather, they would be spoken:

each and every time within a context of temporal depth, performative complexity, and visual density. (...) They were spoken within physical structures each of which was unique in its configuration of endowments, associations, images, organ, choir, and interconnections with local economy and social landscape. They were spoken within a specific physical context, in visual range of particular representations of that body, that blood, within traditions that had already given somatic dimension to those words. ${ }^{98}$

The altarpiece would have formed a very important part of spatial, sensorial and bodily tradition.

Alongside Christ, the martyrs, so vividly present on the shutters in Ringsaker, offered somatic dimensions to the words. In medieval times, the martyrs would be understood as agents contributing to the Treasury of Merit amassed by Christ through his Passion. From a Lutheran perspective, though, these dead bodies possess no religious power. Instead, for Luther, "True power is to be found in faith, meaning interiority is the locus of power and substance, whereas surface is vacuity and form," as stated in Freedom of a Christian and paraphrased in the words of Joshua Mitchell. ${ }^{99}$ Applying ideas about surface and interior to the altarpiece in Ringsaker, it can be construed that for sixteenth-century Catholics the shutters and the saints painted upon them served as protectors - the cover of enigma - of the locus of truth sculpted inside. In contrast, after the Reformation, the multitude of pale, sacrificed bodies on the surface would visualize the "failure" of martyrs, and even of human life in earthly form, as the carnal aspect of Luther's homo. ${ }^{100}$

98 Wandel, The Eucharist, 121.

99 Joshua Mitchell, "Luther and Hobbes on the Question: Who Was Moses, Who Was Christ?," The Journal of Politics 53, no. 3 (1991): 676-700, at 683. Moreover, paraphrasing another of Luther's sermons in the "Commentary to the Galatians," Mitchell postulated, "the troubled consciousness which attempts to comfort itself with the verities of the law cannot be appeased by dwelling on the surface; that is, by works or by the law." Mitchell, "Luther and Hobbes," 685. 100 See for example Ilmari Karimies, "Martin Luther's Early Theological Anthropology: From Parts of the Soul to the Human Person as One Subject," in Subjectivity and Selfhood in Medieval and Early Modern Philosophy, ed. Tomas Ekenberg and Jari Kaukua (Berlin: Springer, 2016), 199-218. 
In addition to an iconography that allowed for a new interpretation in a different religious landscape, the mise-en-scène may have also favoured the preservation of the Ringsaker altarpiece. Might it be that the gilded interior of the altarpiece may have made the altarpiece more compatible with the Lutheran adiaphora? Additionally, given that the sculpted saints are rendered as portraits rather than performing miracles - aside from St Nicholas and the revived three children - they could have been more easily perceived as memory images, divorced of their intercessory powers in the manner of statues removed from altars and hung on the church walls. Yet, some saints lingered on in people's minds, such as the "plague saints" St Gertrude, St Rochus and St Sebastian. Pestilence was still present and to be feared, transmitted to Scandinavia for example in translations of Luther's writings such as Om mand maa fly for Døden oc Pestilentze, en Christelig vnderwisning, printed in Malmø in 1534. ${ }^{101}$

But for some, the entirety of the altarpiece quickly transformed into adiaphora, as an external thing. As noted above, towards the end of the sixteenth century, Bishop Jens Nielssøn wrote that it was a very beautiful altarpiece (saare skiøn taffle), thus referring to the work in aesthetic terms rather than in liturgical or confessional terms, and this sentiment was repeated in the travelogues of Gerhard Schøning. Regarding Schøning’s description, it is also interesting to notice that when he described the work, he recognized the painting with St John the Baptist's martyrdom on the shutter, but failed to name the non-narrative representation of the same saint as a man with a lamb in his hand in the saintly panorama on the inside. ${ }^{102}$ The removal or displacement of sculptures and images in the church interior probably meant Biblical scenes became more prominent; in time, these scenes would then be more familiar to the viewers than non-narrative representations of saints. Although aestheticized in the late sixteenth and the late eighteenth centuries, the Eucharist image remained the quintessential part of the altarpiece. Serving as the locus of truth in medieval times as a (derivative) image supporting the idea of transubstantiation, it also preserved its ontological status after the Reformation, yet with a different reading of the physical material, no longer alluding to what Kirsten van Ausdall

101 Copenhagen, Det Kongelige Bibliotek, Hielmst. $8258^{\circ}$ (LN 156). For the saints' presence before and after the Reformation, see Ragnhild M. Bø, "Material and Immaterial Presence: Engagements with Saints before and after the Reformation in Denmark-Norway," Mirator 19, no. 1 (2018): 84-107.

102 "I det andet Rum sees en Helgen, med blottet Hoved, der har Skiæg og Haar, holdende paa sin venstre haan en aaben Bog hvorpaa ligger et Lam, men for Redtan er han iført en Kiortel, bestaanede af en Dyre-Hud, hvoraf Hovedet nedhænger paa Jorden,” cf. Schøning, En reise, 14. 
refers to as the ingested salvation. ${ }^{103}$ Whether the motif was visually pleasing or theologically significant or both, it nonetheless served as a model for similar depictions in altarpieces carved by local craftspeople in the late eighteenth century, allowing for a dissemination of a somewhat local religious heritage. ${ }^{104}$

\section{Conclusions}

All art may be the product of multiple sources of inspiration and may invariably submit to multiple interpretations, with the Ringsaker altarpiece being no exception. ${ }^{105}$ Produced in a vibrant artistic environment, its prodigious gilding, polychrome sculpture and paintings in the Antwerp Mannerist style resulted in a complex visual blend of images taken from Scripture and hagiography. Within the Antwerp workshop, sculpture and painting were fashioned to fit the devotional needs of a faraway parish, including locally venerated saints, donor portraits of the commissioner and a panorama of saints possibly known from prayers and indulgence letters. All scenes, however, alluded to the central theme of the altarpiece: Christ as the Man of Sorrows placed on an altar, his blood streaming into a chalice.

Withstanding the Reformation, the altarpiece may have been perceived as adiaphora. It may, however, also have been perceived as an artefact displaying human suffering that cannot be alleviated through good deeds or the intercessors depicted on the surface and the shutters. Instead, inner truth and the faith of each individual Christian would emerge in the interior. The embodiment of the Eucharist and the re-enactment of Christ's propitiatory death on the Cross, to which the imagery would have been associated in medieval times, transformed without extensive human intervention - into imagery referring to the same events in a metaphorical sense. ${ }^{106}$ The multivalence and verisimilitude of the

103 For a discussion of material registers in works of art after the Reformation, see Victor Buchli, An Archaeology of the Immaterial (London: Routledge, 2016), 94-131. For a comprehensive study on the role of art in Lutheran tradition, see Bridget Heal, A Magnificent Faith. Art and Identity in Lutheran Germany (Oxford: Oxford University Press, 2017).

104 Examples include the altarpieces carved by Anders Olsen Sæther for the parish churches of Brøttum and Veldre, both made around 1790, see Roar Hauglid, Akantus. Mestrene i norsk treskurd, vol. 2 (Oslo: Riksantikvaren/Mittet, 1950), 315-16. The one in Veldre was consumed by fire in 1996.

105 The seminal approach for understanding works of art from their various "inputs" is Michael Baxandall, Patterns of Intention. On the Historical Explanation of Pictures (New Haven: Yale University Press, 1985).

106 For transitions not of the Man of Sorrow, but the Passion Instruments, see Shannon Gayk, "Early Modern Afterlives of the Arma Christi," in The Arma Christi in Medieval and Early modern 
iconographical program and the mise-en-scène of the narrative in Ringsaker may even have been a deliberate choice by the Antwerp carvers and painters eager to demonstrate their ability to cater to material needs, regardless of their own and/or the commissioner's religious viewpoints.

Acknowledgements: The author would like to thank Wim François (KU Leuven) for commenting on an earlier draft; Kathryn Boyer for meticulous proof reading; and the two anonymous reviewers for their valuable and much appreciated feedback.

Material Culture, ed. Lisa H. Cooper and Andrea Denny-Brown (Farnham: Ashgate, 2014), 273-307. 